ISSN: 0213-2060

DOI: https://doi.org/10.14201/shhme2020382189219

\title{
MIGECIANOS, CASIANISTAS Y LA DEFINICIÓN DE UNA HEREJÍA (FIN DEL SIGLO VIII - PRINCIPIO DEL IX)
}

\author{
Migetians, Casianists and the Definition of a Heresy (End of $8^{\text {th }}$-Beginning of $9^{\text {th }}$ \\ Century)
}

Amancio ISLA FREZ

Departament d'Historia. Facultat de Lletres. Universitat Rovira i Virgili. Avda. Catalunya, 35. E-43002 TARRAGONA. C. e.: amancio.isla@urv.cat

Recibido: 2019-10-09

Revisado: 2020-04-09

Aceptado: 2020-10-26

RESUMEN: Se estudia a los migecianos y casianistas como un grupo con propuestas religiosas ascéticas que fue combatido por Toledo y la Iglesia hispana desde c 780 . Al hacerlo, la Iglesia mostraba su capacidad para mantener viva su antigua función eclesiástica de vigilar las desviaciones religiosas. Migecianos y casianistas fueron definidos como herejes, mientras que la vieja Iglesia reforzaba su posición de ortodoxia y hacía palpable su autoridad. Las acusaciones lanzadas contra migecianos y casianistas nos permiten saber más sobre cuál fue el centro de la polémica. A pesar de la diatriba de Elipando, en estos debates la dicusión sobre las personas y la trinidad no parece haber ocupado el centro del problema; este estuvo concentrado en los temas de convivencia con los no cristianos y, sobre todo, en las cuestiones de autoridad.

Palabras clave: Herejía; Migecio; Adopcionismo; Reliquias; Historia de la Iglesia; Iberia en la temprana Edad Media; Carolingios.

ABSTRACT: Migetians and Casianists are studied as a group with ascetic religious proposals which was fought by Toledo and the Hispanic Church since ca 780. Doing so the Church showed its capacity to maintain its old ecclesiastical function of monitoring religious deviations. Migetians and Casianists were defined as heretics while the old Church reinforced its condition of orthodoxy and made evident its authority. The accusations launched against Migetians and Casianists allow us to know more about what was at the centre of the controversy. Despite Elipandus' diatribe, disputes on the persons or the trinity do not seem to have had a fundamental role. The controversy focused in the coexistence with non-Christian populations and above all on authority. 
Keywords: Heresy; Migetius; Adoptionism; Relics; Church history; Early Medieval Iberia; Carolingians.

SUMARIO: 0 Introducción. El adopcionismo y la tradición hispana. 1 La misión carolingia. 2 Las manifestaciones de Migecio y la reacción a las mismas. 3 El nombre de la cosa. 4 Los debates in situ. 5 El Mediterráneo, Roma y los carolingios. 6 Conclusión. 7 Referencias bibliográficas.

Llamamos adopcionismo a una corriente interpretativa cristológica que se desarrolló en el ámbito hispano a partir de los últimos años del siglo viII, manifestándose en escritos de los obispos Elipando de Toledo y Félix de Urgell. Esta tenía como preocupación central las relaciones del hombre-Cristo, es decir, de la naturaleza humana de Cristo con el Padre. Sus opiniones tuvieron eco más allá de la Península y fueron condenadas en el concilio de Frankfurt de 794.

La tradición historiográfica, tanto antigua como reciente, hispánica como extrahispánica, ha insistido en la presentación del adopcionismo como una herejía. En la caracterización y filiación del adopcionismo influye notablemente el concepto general que se tiene de las formulaciones teológicas, más aún de aquellas que acaban al margen de las consideradas ortodoxas. Esta herejía sería contemplada de dos maneras en el fondo coincidentes. La propuesta adopcionista expresaría una voluntad de aproximación al Islam, en tanto que humanizaría la figura de Cristo, distanciándola del Padre ${ }^{1}$, o bien, pero en una línea no muy diferente, sería un acercamiento al nestorianismo que, siguiendo con esta percepción, unos sirios nestorianos, que vendrían con algún grupo de inmigrantes musulmanes, habrían difundido en la Península, de modo que un metropolitano de Toledo podría haberla asumido. La única ventaja de este último planteamiento es poner de relieve cuán relacionada está la polémica con los debates sobre Cristo y sus naturalezas.

En cualquier caso, también se ha destacado desde antiguo que el debate tiene que ver con la situación debilitada de la Iglesia visigoda, ahora sometida y sin capacidad para organizar concilios que hubieran puesto coto a las "particulares cavilaciones» de los adopcionistas ${ }^{2}$. Se trata de una percepción muy en la línea del combate heresiológico que explica la aparición de la herejía por la debilidad de la autoridad eclesiástica para reducirla. Mas, a pesar de

1 Vid., Oliver, Antonio. «Félix de Urgel y el adopcionismo». En García Villoslada, Ricardo (ed.). Historia de la Iglesia en España. Madrid: Biblioteca de Autores Cristianos, 1979, vol. II, tomo 1, p. 89. En este sentido se aproximaría también al arrianismo. Estudios relevantes desde esta perspectiva son los debidos a Rivera Recio. Vid., Rivera Recio, Juan Francisco. Elipando de Toledo. Toledo: Editorial Católica Toledana, 1940; y su El adopcionismo en España (s. VIII). Toledo: Seminario Conciliar de San Ildefonso, 1980. Ha calado la idea de señalar a Elipando como un aproximador de la vieja religión a la nueva: TiEsZEN, Charles. Christian identity amid Islam in medieval Spain. Leiden: Brill, 2013, p. 36.

2 Menéndez y Pelayo, Marcelino. Historia de los heterodoxos españoles. Madrid: Librería Católica de San José, 1880, vol. I, p. 301. 
las necesarias matizaciones, esta explicación resalta aspectos relevantes a la hora de bosquejar el marco cultural y religioso de la sociedad en que se desarrolló la polémica.

Por nuestra parte, hemos abundado en dos vías de interpretación ${ }^{3}$. La primera es subrayar la mínima posibilidad de que Félix de Urgell, los cordobeses o, más aún, Elipando estuvieran abiertos a aproximaciones hacia el Islam. Nada en sus textos hace pensar de la mayoría de ellos un conocimiento siquiera mediocre de la fe islámica o, por supuesto, de la lengua árabe. Insisto especialmente en el caso del metropolitano de Toledo quien, por su edad -habría nacido muy poco después de la conquista, en 717-, difícilmente mantendría contactos con los musulmanes o con los sirios nestorianos, verdadero deus ex machina de la propuesta. Difícil es suponer un acercamiento al Islam de Félix, quien nos consta que escribió un tratado anti-islámico ${ }^{4}$, y que parece haber recopilado en su obra el material antimahometano que corría por el Mediterráneo, ferozmente crítico con la figura de $\mathrm{Mu}$ hammad. Nuestra opinión es que estos debates tenían que ver con apreciaciones enraizadas en la Iglesia hispana que podemos ver en su liturgia o en la obra teológica de diversos estudiosos, especialmente de Julián de Toledo. Si queremos presentarlo con claridad, creemos que la Iglesia hispana era profundamente partidaria de la doble naturaleza de Cristo y se mostraba nada proclive a considerar cualquier elemento que sonara a fisura del programa del concilio de Calcedonia, reunido en el año 451. La polémica de los Tres Capítulos y el enfrentamiento a la política religiosa del emperador Justiniano y sus sucesores alcanzó su cenit en el momento de la conversión de los visigodos y consolidó una percepción calcedoniana diamantina ${ }^{5}$. El núcleo de la tradición teológica hispana se había forjado en la oposición al arrianismo, incluso a cualquier forma suavizada del mismo, y en el enfrentamiento a quienes consideraban acéfalos, es decir, a corrientes que debilitaran la humanidad del Hijo.

La repetición litúrgica había familiarizado a los hispanos con la terminología de la adopción, de manera que la entendían como la vía normal para explicar unas complejas relaciones en la Trinidad. Mas otras tradiciones occidentales estaban completamente al margen de estos usos y la innovación en estos temas ya era sospechosa por sí misma. Una sensación similar se producirá cuando Elipando revele a sus lectores extrahispánicos quiénes eran los autores en los que sustentaba sus opiniones. Se generará en Alcuino de York un rechazo por el distanciamiento o, más bien, el desconocimiento de unos personajes, como eran Ildefonso, Eugenio o Julián de Toledo, que en el antiguo reino godo eran tenidos como referentes intelectuales, pero que resultaban nombres vacíos lejos de esta cultura. Esta ignorancia y el alejamiento de las respectivas coordenadas fueron un elemento decisivo para explicar la polémica.

3 Vid., Isla Frez, Amancio. «El adopcionismo y las evoluciones religiosas y políticas del reino astur». Hispania, 1998, vol. 58, n. ${ }^{\circ}$ 200, pp. 971-993; y «El adopcionismo. Disidencia religiosa en la Península Ibérica (fines del siglo viII-principios del siglo Ix)». Clio \& Crimen, 2004, vol. I, pp. 114-134.

4 Félix escribió la Disputatio Felicis cum Sarraceno, obra no conservada, pero mencionada por Alcuino. Este sabía de su existencia, pero todavía no la había manejado: nec vidi nec apud nos inventa est, aunque parece que Leidrado de Lyon tenía un ejemplar (Ep., n. ${ }^{\circ}$ 172, fechada en 799, DüMmLER, Ernest (ed.). Monumenta Germaniae Historica. Epistolae Karolini aevi. Tomus II. Berolini: Apud Widmannos, 1895).

5 Sobre esta polémica, aunque con muy limitado interés por la situación en el reino visigodo, vid., Chazelle, Celia y Cubitt, Catherine (eds.). The Crisis of the Oikoumene: The Three Chapters and the Failed Quest for Unity in the Sixth Century Mediterranean. Turnhout: Brepols, 2007. 
El distanciamiento de la cristiandad hispana con respecto a la del resto de Occidente queda de manifiesto merced a una operación en la que participaron el papado y la Iglesia franca. Se han conservado unas cartas, luego incorporadas en el Codex Carolinus junto a otras misivas cruzadas entre los reyes francos y Roma ${ }^{6}$, que nos informan de la misma. La empresa consistió en enviar a la Península a un obispo, un hispano de nombre Égila, propuesto y ordenado como tal por Wilchario de Sens con el consentimiento del papa Adriano. Égila fue enviado ad praedicandum, es decir, se le asignaba una dedicación que presuponía un lamentable estado del cristianismo en Hispania y, aunque de manera vaga, se insistía, además, en la leyenda de la predicación romana en Hispania que ahora debería restaurarse ${ }^{7}$. Claro es que ahora se hacía con la intermediación de la Iglesia y la monarquía franca que promocionaba la expansión de la autoridad romana hacia la Península. Wilchario tampoco era cualquier obispo: había sacralizado a Carlos en 771, tras la muerte de Carlomán, y había ostentado el título de archiepiscopus Galliae en el concilio de 769, en donde encabezó un nutrido grupo de obispos llegado a Roma desde el reino franco ${ }^{8}$. Es este jefe oficial del episcopado franco - por utilizar la expresión de Duchesne- quien dinamiza la operación que habría de contar con el beneplácito regio y que traducía ciertas expectativas con respecto a los espacios y sociedades a intervenir?.

La misión de Égila no implicaba la ocupación de una sede concreta, sino precisamente una predicación extensiva. Propiamente no era un chorepiscopus $^{10}$, pues no llevaba aparejada una condición rural y, por supuesto, no era subsidiario de otro prelado. Más bien se reproducía un sistema que había existido desde época del Imperio romano, donde algu-

6 Ya constituye un problema el motivo de su conservación, si bien revela el interés carolingio en los nexos con el papado y en el desarrollo de la misión. Su fecha fue revisada por Bullough, Donald. «The Dating of Codex Carolinus n. ${ }^{\text {s }}$ 95, 96, 97, Wilchar, and the Beginnings of the Archbishopric of Sens». Deutsches Archiv für Erforschung des Mittelalters, 1962, vol. 18, n. ${ }^{\circ}$ 1, pp. 223-230. Señala a las 96 y 97 como escritas con anterioridad, debiendo datar la 95 en 786 y enmarca la operación en el deseo carolingio de obtener el control sobre la Iglesia hispana (p. 224).

7 Codex Carolinus. n. 0 95: sancta nostra catholica et apostolica olim predecessores vestri a sanctis nostris predecessoribus susceperunt... Parece que se acude a la leyenda de los varones apostólicos.

8 Duchesne, Louis. "Wilchaire de Sens, archevêque des Gaules». Bulletin de la Société Archéologique de Sens, 1895, vol. 17, pp. 15-22. Duchesne ya comparó las atribuciones de Égila con las de Bonifacio en Baviera y Suabia (pp. 18ss); quizá en un sentido tan difuso como el venit... regere res ecclesiasticas (BITTERAUF, Theodor. Die Traditionen des Hochstifts Freising. I Band (744-926). München: M. Rieger'sche UniversitätsBuchhandlung: 1905, p. 216; TF, 234a). Sobre esta misión, Close, Florence. Uniformiser la foi pour unifier l'empire. Bruxelles: Académie Royale de Belgique, 2011, pp. 56ss.

9 Había calificado esas posturas carolingias de imperiales («El adopcionismo», p. 975), suscitando la crítica de Close, pero mi pretensión era subrayar unas dinámicas genéricas con una larga tradición que se remonta al Imperio romano cristiano; ahora en un sentido similar, Nelson, Janet L. King and Emperor. A New Life of Charlemagne. Oakland: University of California Press, 2019, pp. 305ss. Nelson presenta los intereses de Carlomagno en su combate contra la herejía. También RaAjumakers, Janneke E. y van Renswoude, Irene. "The ruler as referee in theological debates: Reccared and Charlemagne». En MeENs, Rob et al. (eds.). Religious Franks. Religion and Power in the Frankish Kingdoms. Studies in Honour of Mayke de Jong. Manchester: University Press, 2016, pp. 51-71.

10 Hefele recogió buena cantidad de ejemplos (Hefele, Charles-Joseph. Histoire des conciles d'après les documents originaux. Paris: Letouzey et Ané, 1908, vol. II, pt. 1, pp. 1197ss). 
nos obispos eran ordenados y enviados para actuar sobre poblaciones enteras ${ }^{11}$; también a pueblos en los que podía haber paganos y cristianos, como la operación encargada a Agustín en Inglaterra por Gregorio Magno. Esta misión hispana y el contenido de las quejas y los problemas que se describen al hilo de la misma suscitaron en la historiografía una impresión muy negativa sobre la situación del cristianismo y de la Iglesia durante el emirato. Una impresión que convendría revisar.

\section{LAS MANifestaciones de Migecio y la REACCión a LAS Mismas}

El tratamiento historiográfico del adopcionismo suele iniciarse a partir de la aparición en medios hispanos de unas opiniones consideradas heréticas, las de Migecio. Serán las respuestas de Elipando a estas posiciones teológicas las que enciendan la polémica. No obstante, nuestra atención no quiere insistir en un encadenamiento histórico de las polémicas, sino que se dirige a este estadio de la polémica, a la controversia suscitada y a cómo se pudo entender en medios hispanos.

La historiografía tradicional había insistido en el triste estado en todos los niveles de la cristiandad peninsular tras la conquista. Desde su perspectiva, se instalaría una situación de abatimiento y menoscabo y se difundiría un desorden que vino a promover las discordias religiosas y el desarrollo de graves errores ${ }^{12}$. Abadal, en cierto modo, vino a suscribir alguna de estas opiniones, en tanto que destacaba «las deformaciones espirituales de la época» ${ }^{13}$, si bien en su opinión la eclosión de estas dinámicas tenía que ver con el desplome de la Iglesia visigoda. Vamos a señalar que ese diagnóstico debe ser matizado, que, si las dificultades fueron apreciables en el terreno disciplinar, en otros aspectos y decididamente en el cultural estaban en las viejas coordenadas visigodas.

La caja de Pandora había sido abierta por una polémica contemporánea, un conflicto que había sacudido a la Iglesia hispana hacia el 780 y que se prolongaría unos años. Este se había generado a partir de las propuestas de un tal Migecio, quien había promovido en medios hispanos unas ideas que combinaban opiniones trinitarias propias con un mensaje rigorista. No sabemos casi nada del personaje ni de sus planteamientos. Nuestro conocimiento depende de las informaciones que nos suministran sus oponentes. Estas son, además, bastante esquemáticas, puesto que se trata de señalar aspectos y describirlos para poner de manifiesto el error teológico y la degradación moral del colectivo que se pretende condenar ${ }^{14}$. Nos encontramos, pues, con los efectos de esa tendencia propia de los heresiólogos de hacer equivaler una herejía a otras anteriores, trazando su genealogía con los pertinentes

11 Mathisen, Ralph W. «Barbarian Bishops and the Churches "in Barbaricis Gentibus" during Late Antiquity». Speculum, 1997, vol. 72, n. ${ }^{\circ}$ 3, pp. 664-697.

12 "Triste era el estado de la Península...», vid., Menéndez Pelayo, Historia de los heterodoxos españoles, vol. I, pp. 265ss; en línea semejante Simonet, Francisco Javier. Historia de los mozárabes de España. Madrid: Est. Tip. de la Viuda e Hijos de M. Tello, 1897-1903, p. 261.

13 ABADAL, Ramon d'. La batalla del adopcionismo en la desintegración de la Iglesia visigoda. Barcelona: Real Academia de Buenas Letras, 1949, p. 48.

14 Lo resume bien Próspero cuando dice de los maniqueos, sacra eorum tam nefanda quam mores (Epit., 919, MGH, AA, I, p. 444). 
parentescos ${ }^{15}$. Una opción religiosa que se quiere denigrar ha de ser reconocida, derivándola o poniéndola en paralelo con otras que ya se han asumido como ideas despreciables y peligrosas que en su momento habían sido reprobadas. Se trata, pues, de acercar dos imágenes para que puedan percibirse homogeneidades que avalen la condena de un planteamiento religioso nuevo. Desde esta perspectiva, la novedad, en realidad, sería solo aparente, en tanto que las herejías se asemejan unas a otras y todas ellas entre sí. Este método genético y comparativo permite encuadrar la 'nueva' propuesta dentro del organigrama general y, por supuesto, fundamentar así la condena.

Como decimos, cualesquiera que fueran las opiniones de Migecio, solo cabe conocerlas a través de sus detractores, cuyo objetivo prioritario era, no tanto realizar un estudio de la teología propuesta o de otras ideas o prácticas que formularan, sino justificar su condenación. Dicho de otra manera, conviene ser precavido ante lo sesgada que pueda ser la información disponible. Sin embargo, creemos que esos apuntes no son casuales, que a partir de estas críticas se suministran pinceladas - ahora por la carta que escribió Elipando respondiendo a Migecio- que nos permiten algún conocimiento de lo que se discutía. En nuestro caso, además, existió un documento salido de la pluma de Migecio, suficientemente conocido para que el obispo toledano tuviera que referirse a él. En efecto, gracias a la epístola elipandiana, sabemos que Migecio había escrito una obra bajo la forma de carta. Este tratado debió de haber circulado por algún tiempo cuando el metropolitano de Toledo decidió contestar, puesto que, como explicita, en un primer momento le habían llegado rumores de la difusión de sus peculiares opiniones entre los ignorantes y solo después tuvo en sus manos la obra en cuestión. Es el texto de Migecio el elemento que desencadena la reacción, una respuesta que utiliza un género similar y que revela la continuidad de estos procedimientos que enlazan con los de la Antigüedad tardía. La epístola de Elipando, a su vez, constituye un serio trabajo de polémica antiherética, siguiendo los parámetros habituales del género: desentrañar, atacar y refutar las opiniones teológicas, más criticar y vilipendiar las actitudes morales e intelectuales de quienes las proponen. Como vemos, en el último cuarto del siglo viII en el al-Andalus cristiano se producían controversias religiosas a través de materiales escritos, suficientemente difundidos para que alcanzaran un público amplio merced a lecturas privadas o, presumiblemente, incluso públicas. Estas disputas desbordaban el marco político emiral, se expandían por el resto del espacio del antiguo reino visigodo, alcanzando los territorios norteños peninsulares, y llegaban hasta Roma y el ámbito franco.

Entre estas críticas destaca una que aparece ya antes de entrar en materia. Migecio se ha puesto a elucubrar en el terreno de la teología cuando carece de la suficiente formación. Por tanto, resulta un personaje soberbio -siendo la soberbia la raíz del pecado y del error-, que no ha estudiado humildemente con anterioridad, sino que, como el obispo establece ya desde estas primeras líneas, ha escogido el camino de engañar a quienes lo rodean. La actuación de Migecio va en sentido contrario a las prácticas comunes y de la Iglesia: primero hay

15 Lo había hecho Jerónimo al escribir sobre el pelagianismo (Dialogus adversus Pelagianos, Prol.; Moreschini, C. (ed.). Turnhout: CCSL-80, 1990; también, Ep. 133. Hilberg (ed.). Viena: CSEL-56, 1918). Muy pertinente, Elm, Susanna. "The polemical use of genealogies: Jerome's classification of Pelagius and Evagrius Ponticus». En Livingstone, Elizabeth (ed.). Augustine and his Opponents. Studia Patristica, 1997, vol. XXXIII, pp. 311-318. 
que aprender para poder, luego, enseñar ${ }^{16}$. Así, frente a esa actitud inapropiada se preconiza la contraria, la del lento aprendizaje al que ha de someterse quien, después, dispone de un conocimiento que puede a su vez impartir: obviamente se subraya el principio de autoridad. Es Toledo quien está en disposición de manifestarse sobre estos temas y de señalar la recta fe. No es baladí que esta acusación figure en primer lugar. El origen de su 'condición herética' y en general del problema que plantea es su desapego con respecto a las pautas tradicionales, las que son salvaguardadas por Toledo y la organización eclesiástica. Desde esta perspectiva entendemos mejor el sentimiento que pudo formarse en Elipando y los toledanos cuando nuevos planteamientos disonantes llegaran desde el Norte peninsular. La de Beato de Liébana no fue una primera incidencia, sino que pudo ser percibida como un nuevo golpe dentro de una dinámica generalizada contra la herencia teológica y, claramente, organizativa y disciplinar. Frente a estas amenazas surgidas en los nuevos tiempos, cabía acudir a quien había garantizado la recta fe durante tantos siglos, Toledo. La tradición y el alejamiento de la misma eran una nota destacada para calibrar la herejía. Vicente de Lerins ya había subrayado que hay dos principios para estimar o no la ortodoxia de una propuesta, la acomodación a la ley divina y el encuadramiento en la tradición ${ }^{17}$. Así, la insistencia en moverse dentro de los cauces transitados por los antepasados no era accidental, suponía una garantía de ortodoxia frente a unas posiciones que aparecían como novedosas o diferentes ${ }^{18}$.

Los herejes son caracterizados por el hedor que exhalan. Se trata de una imagen denigratoria que se contrapone a la fragancia que procede de la santidad, una fetidez que se relaciona con la muerte y el pecado y sus efectos de podredumbre y, en buena medida, con el engaño y los sepulcros blanqueados que cubren la pestilencia de su interior. Por supuesto, con el maloliente demonio ${ }^{19}$. Con esta actitud engañosa actuaban de manera comparable al de otros colectivos deseosos de seducir y llevar a los cristianos al error.

Sus detractores denominaron a estos colectivos casianos (Casiani), etiquetándolos con un marchamo sobre el que volveremos. Nuestras referencias insisten en su condición de sabelianos, es decir, de partidarios de las doctrinas de Sabelio, un teólogo del siglo iII que

16 Se cita, no literalmente, a Gregorio Magno (Regula pastoralis, 1; Judic, Bruno (ed.). La Règle pastorale. Sources Chrétiennes, 381. Paris: Éditions du Cerf, 1992).

17 Primum scilicet diuinae legis auctoritate, tum deinde ecclesiae catholicae traditione (Commonitorium, II (1). Demeulenaere, R. (ed.). Turnhout: Brepols, CSSL-64, 1985).

18 Dominique Urvoy ha señalado que con sus propuestas Migecio haría más complicada la convivencia con los musulmanes, algo que Elipando, a la cabeza de la Iglesia oficial, habría de responder en aras de algún grado de entente con los dominadores. En estas concepciones los migecianos coincidirían luego con Beato y los norteños (Urvoy, Dominique. "The Christological Consequences of Muslim-Christian Confrontation in Eighth-Century Spain». En Fierro, M.a Isabel y Samsó, Julio (eds.). The Formation of al-Andalus, 2: Language, religion, culture and sciences. Aldershot: Taylor \& Francis, 1998, pp. 37-50). No obstante, estas posiciones rupturistas adjudicadas a los migecianos no son plenamente consistentes, tanto en los aspectos teológicos como en los de la cotidianeidad. Además, su distanciamento no solo afectaba a la comunidad musulmana como a otros cristianos, mientras su afirmación romana los alejaba de las estructuras hispanas. Esta aproximación entre migecianos y anti-adopcionistas está apuntada también en URVoy, Dominique. «La pensée religieuse des mozarabes face à l'islam». Traditio, 1983, vol. 39, pp. 426ss, sugiriendo, al tiempo, un acercamiento de Elipando a los musulmanes que no suscribimos.

19 Deja su fetidez en la celda de Martín (Sulpicio Severo. Vita Martini, 24, 8, Halm, K, (ed.). Viena: CSEL-20, 1866). 
convertía a las tres personas en meros modos de presentarse de un único Dios que era verdaderamente uno (por tanto, monarquianismo), si bien estas manifestaciones se producían en el tiempo (modalismo) ${ }^{20}$. La caracterización parece concordar bastante con las opiniones de Migecio, en el sentido de que Dios Padre se habría manifestado specialiter como David, Cristo era la expresión también en el tiempo de la segunda persona y Pablo del Espíritu, igualmente ${ }^{21}$. Más que admitir un profundo desvarío teológico de Migecio, creo probable que su intención fuera destacar que David era el padre de la humanidad de Cristo $^{22}$, que había una asunción por parte de la divinidad del nacido de la Virgen y que el Espíritu habitaba en Pablo ${ }^{23}$. Quizá ideas un tanto simplistas y, desde luego, de cierta tosquedad en el terreno del debate teológico trinitario en el que serían escrutadas, desmenuzadas y, si convenía, caricaturizadas. Esa afirmación de unicidad divina sin subrayar la realidad y triplicidad de las personas explica la caracterización de nuestro personaje como sabeliano ${ }^{24}$. La propuesta

20 La obra de Elipando está editada en GiL, Juan. Corpus scriptorum muzarabicorum. Madrid: Consejo Superior de Investigaciones Científicas, 1973, I. Migecio es definido como Casianorum et Salibaniorum magister en la carta de los obispos hispanos a los francos (Ep. IV, 5; GIL (ed.), Corpus, I, p. 92; también en $M G H$, Concilia, II, 1, p. 118). Cavadini piensa que puede haber en el término magister Salibaniorum una connotación nestoriana por vía del árabe (CAvadini, John C. The Last Christology of the West. Adoptionism in Spain and Gaul, 785-820. Philadelphia: University of Pennsylvania Press, 1993, p. 23). Significaría entonces 'maestro de los cristianos/nestorianos', con lo que no se entiende por qué lo emplearían otros cristianos, además en el contexto de remitirlo a la cristiandad occidental.

21 Según Isidoro, propugnan que una misma es la persona del Padre, del Hijo y del Espíritu (Etym., VIII, 5, 42. Lindsay, W. M. (ed.) Oxford: Oxford University Press, 1911). Los sabelianos defienden una falsa Trinidad (Agustín de Hipona. De civitate Dei, X, 10, 1. Hofmann, E. (ed.). Viena: CSEL-40, 1899). También sobre ellos, Agustín de Hipona, De haeresibus, XLI. PL, 42, col. 52. Vid., Pelikan, Jaroslav. The Christian tradition: A history of the development of doctrine, vol. 1: The emergence of the Catholic tradition (100600). Chicago: University of Chicago Press, 1975, pp. 179ss.

22 Quizá sobre la base paulina: ex semine David secundum carnem (Rom., 1, 3). La filiación davídica está muy presente en los sinópticos: muy especialmente, Mat., 1, 1. Además, Mat., 22, 42-43; Marc., 12, 35; Luc., 20, 41. John Cavadini sostiene que, tal y como suenan, las afirmaciones de Migecio son absurdas (The Last Christology of the West, p. 15), pero propone un recorrido del pensamiento migeciano a través de la crítica de Elipando que destaca la 'formalidad' y propiedad de sus opiniones, sosteniendo tres personas creadas y corpóreas que fueron asumidas por la divinidad (pp. 17ss).

23 Probablemente a partir de 1 Cor., 7, 40; siendo Pablo quien representaría esa sabiduría divina que habita en él (Rom., 8, 11), en la línea de 1 Cor., 2, 10-16. Cavadini afirma que Migecio señalaba tres instancias de la aparición de Dios en la Historia, una por cada persona de la Trinidad, implicando cada vez la unión con una persona asumida (The Last Christology of the West, p. 20).

${ }_{24}$ En los manuscritos aparece la forma Salibanorum que resulta incomprensible. Fue Gregorio Mayans $(\dagger 1781)$ quien afinó la lectura del manuscrito -suponiendo un error de lectura, posible para alguien no familiarizado con la letra- y propuso que el «Salibanorum magister» que aparecía en el mismo remitía a los sabelianos. Su apunte y enmienda llegaron a Frobenius de San Emerano de Ratisbona († 1791), quien preparaba una edición de la obra de Alcuino (publicada en la misma abadía en 1777) y quien dejó constancia de la hipótesis pergeñada por el clarissimus Mayans (Opera, I, p. 956). Además, allí Mayans refiere que ignora la procedencia del nombre casianista, pero cree en la posibilidad de que se trate de una manera de referirse a los donatistas, debido a que este Donato a Casis nigris in Africa Episcopus fuerat. De aquí lo tomó Johann Baptist Enhueber, quien fuera prior de San Emerano $(\dagger 1800)$ y realizara una Dissertatio para la edición corregida de las obras de Alcuino, la Dissertatio dogmatico-historica (XXXI, p. 956), luego insertada por Migne en su Patrología. 
migeciana no solo fue ridiculizada, sino también llevada por Elipando a los terrenos del sabelianismo, una herejía suficientemente tipificada en la apologética.

Una fuente redactada unas décadas más tarde se refiere a estos casianos como acéfalos ${ }^{25}$. Sabemos, por otro lado, que la Iglesia visigoda designaba como acéfalos a quienes defendían posiciones monofisitas. Recibían esta denominación, al decir de Isidoro de Sevilla, porque no tenían un heresiarca primordial que les diera nombre ${ }^{26}$, una especie de gran fundador, al modo de Arrio o Nestorio, un auctor erroris. Lo fundamental era su afirmación de una única naturaleza en Cristo y su negativa a aceptar su naturaleza humana y sus implicaciones. Y así Isidoro de Sevilla señalaba a emperadores -Zenón, Anastasio o, destacadamente, Justiniano- como defensores de sus ideas y contrarios a lo dispuesto en el concilio de Calcedonia ${ }^{27}$.

Este paralelismo entre el monofisismo y el sabelianismo, como impulsores de una única naturaleza, explica el uso de los dos términos - de acéfalos y de sabelianos- como sinóni$\operatorname{mos}^{28}$. Así, en una interpolación inserta en la Chronica muzarabica que recoge algunos de los méritos del metropolitano Cíxila de Toledo, se narra su enfrentamiento en la segunda mitad del siglo viII con un personaje que es descrito como sabeliano ${ }^{29}$. Obviamente hay que entender alguna persona, quizá proveniente del Oriente mediterráneo, partidario de posiciones monofisitas. Quien lo caracterizó vino a emplear una sistemática similar a la de Elipando, estableciendo su nexo con una herejía ya codificada como tal. En definitiva, se mantenía vigente un modo de interpretar planteamientos religiosos que se entendían como distanciados de Calcedonia.

\section{El NOMBRE DE LA COSA}

Más compleja, en cambio, es la denominación de casianos con que estos discrepantes aparecen en los textos. Conviene advertir que es un apelativo que no reciben en la epístola de Elipando, sino que aflorará algo más tarde, en la carta hispana a los obispos francos, probablemente redactada por el metropolitano, y en las actas del concilio del $839^{30}$. De hecho, es la referencia de los obispos hispanos a los migecianos como casianos la que nos permite

25 Quosdam Acebaleos nomine Casianorum (Concilio de Córdoba del 839; Gil (ed.), Corpus, I, p. 135).

26 Etym., VIII, 5, 66. En el mismo sentido Chronica, 385. Martín, José Carlos (ed.). Chronica. Turnhout: Brepols, CCSL-112, 2003, p. 185. Sobre estas cuestiones, BArbero, Abilio. «El conflicto de los Tres Capítulos y las iglesias hispánicas en los siglos vi y viı». Studia Historica. Historia Medieval, 1987, vol. 5, esp. p. 134.

27 Chronica, 386, 389 y 397 (Martín, J. C. (ed.). Isidori Hispalensis opera).

28 Emplea sabeliano también Víctor de Vita para describir a quienes eran anticalcedonianos, es decir, partidarios de una única naturaleza (Historia persecutionis, II, 6, 69. Halm, Karl (ed.). MGH, AA, III, 1).

${ }^{29}$ Homo heresem Sabellianam seductus... a demonio est arreptus... sanum redidit et illesum (Anónimo mozárabe, 72, Gil (ed.), Corpus, I, p. 48 nota. Interpolación de los manuscritos M y P, que proceden del perdido códice de Alcobaça). Simonet sugirió que este sabeliano podría ser alguien influido por las unitarias creencias coránicas (Historia de los mozárabes de España, pp. 207ss y p. 261).

30 Migecio es el Casianorum et Salibaniorum magister en la carta de los obispos hispanos a los francos (Ep. IV, 5. Gil (ed.), Corpus, I, p. 92. Werminghoff (ed.). MGH, Concilia, II, 1, p. 118). Werminghoff data la carta de los obispos en 792-793. Casianos son denominados los condenados por el concilio (GIL (ed.), Corpus, I, pp. 135ss). 
afirmar que los conciliares reunidos en Córdoba entendieron a quienes condenaron como herederos de Migecio y los suyos. La denominación, pues, no parece ni ser propia o autoasignada, ni sugerida en un estadio inicial por su primer debelador, y es posible, incluso, que se haya ido afirmando a lo largo de la controversia.

Cabe que estemos ante una alusión a Juan Casiano, el promotor monástico de la primera mitad del siglo v. Sus obras de tema ascético tuvieron un enorme prestigio en Occidente. Casiano, además, escribió un tratado contrario al nestorianismo que le había sido encargado por León, entonces archidiácono, pero que luego alcanzaría el pontificado ${ }^{31}$. Fue una obra muy difundida y que no suscitó ninguna crítica en su tiempo. De hecho, allí alumbraba algunas similitudes entre Nestorio y Pelagio, apuntando en ellos una misma potenciación del hombre-Cristo, pues era su dignidad como hombre la que lo había hecho ser merecedor de la divinidad. No hay, pues, un vínculo entre el Casiano histórico y unos esquemas cristológicos antinicenos o anticalcedonianos.

Entre las descripciones del colectivo destaca su rigorismo, que reforzaban sintiéndose diferentes y alejándose de los demás, al tiempo que se pretendían menos transigentes con las faltas humanas. Migecio insistía, por ejemplo, en que los presbíteros que pecaban dejaban de ser tales ${ }^{32}$. Quizá por ello algunos estudiosos pensaron que con la denominación de casianistas se aludía a las propuestas del africano Donato, que habría nacido o habría sido obispo en Casae Nigrae (Numidia) y que amparaba negar la capacidad sacerdotal a quienes hubieran pecado, como parece que hacían (o sugerían) estos migecianos ${ }^{33}$. Sin embargo, el personaje africano aparece mencionado, todo lo más, como Donatus Casensis, sin que florezca ninguna otra variante ${ }^{34}$. En cualquier caso, los seguidores de este movimiento rigorista recibieron históricamente la denominación de donatistae o alguna otra, pero nunca la de casianistas. Ello sucede tanto en las referencias hispanas, por ejemplo en Isidoro de Sevilla, como en las provenientes de otras regiones occidentales, ya sean las más antiguas o en menciones más recientes.

Gams, por su parte, sugirió que estos casianistas estarían relacionados con la advocación de una iglesia, dedicada al santo africano de este nombre, un centro que él supone radicado en Cabra, en virtud de la información proporcionada por el concilio del $839^{35}$. Sin embargo, aunque derivamos algún conocimiento hispano del mártir tingitano gracias a la mención que de él hace Prudencio, no es sino una afirmación con una mínima apoyatura,

31 De incarnatione Christi. Petschenig, Michael (ed.). Iohannis Cassiani Opera. I, Viena: Apud C. Geroldi Filium, 1888, CSEL-17.

32 Elipando, Ep., I, In Migetium, 10.

33 Así lo señala J. B. Enhueber en su Dissertatio (PL, 101, col. 357).

34 Además, tras larga discusión, hoy se cree que estamos ante una mala lectura. Como Donatus Casensis aparece mencionado por Agustín de Hipona o por Optato e, incluso, en algún concilio. Durante bastante tiempo hubo dudas sobre la personalidad (una o doble) de este Donato, ahora resueltas en favor de un único personaje y de la lectura Carthaginensis: Vid., Barnes, T. D. "The Beginnings of Donatism». The Journal of Theological Studies, 1975, vol. 26, n. ${ }^{\circ}$ 1, pp. 13-22; Alexander, James S. "The Motive for a Distinction between Donatus of Carthage and Donatus of Casae Nigrae». The Journal of Theological Studies, 1980, vol. 31, n.o 2 , pp. $540-547$.

35 Los conciliares sitúan esta comunidad en un lugar que uocitatvr Epagro territorio Egabrense (9, p. 141). Epagro está en la vía entre Antequera y Córdoba, según el Ravenate, y parece referirse a la actual Aguilar de la Frontera, que ubica en territorio dependiente de Cabra que fue sede episcopal en época visigoda. 
pues no disponemos de fuente alguna que avale la existencia del culto y de esta iglesia ${ }^{36}$. Por otro lado, resultaría algo extraño designar a un grupo cuya condición de herejes se quiere destacar con el nombre de un santo.

Una posibilidad más firme podría ir en una línea ya apuntada por Hefele. El término aludiría a Juan Casiano, convertido ahora en hereje, en razón -creyó Hefele- de sus posiciones semipelagianas ${ }^{37}$. Con el término semipelagianismo -una etiqueta historiográfica- tratamos de dibujar una posición sobre la gracia y la predestinación que se desarrolló fundamentalmente en el Sur de las Galias frente al despliegue de las opiniones agustinianas. Solemos establecer en el desarrollo de este debate un polo ascético y monástico, representado por Juan Casiano o Fausto de Riez, frente a las opiniones pro-agustinianas propugnadas por Próspero de Aquitania. El núcleo central visto desde la perspectiva ascético-monacal era que la industria, los esfuerzos del monje por desarrollar una vida modélica, eran reducidos a la nada en función de una afirmación absoluta de la gracia. Casiano era partidario de una gracia cooperativa con la libre voluntad humana, capaz de instar y promover (el initium conversionis), actuando -quizá de un modo harto impreciso- con la gracia. Por otra parte, una predestinación tal y como la fue proponiendo Agustín, podía limitar toda capacidad humana de contribuir a la propia salvación ${ }^{38}$.

Tras un largo período de tensión y de indecisión, las propuestas de los que llamamos semipelagianos fueron condenadas por el concilio de Orange de 529. En el concilio se ponía de manifiesto el movimiento de la Iglesia meridional gala dirigida por Cesáreo de Arles hacia posiciones sostenidas por el papado, acuerdo y alineamiento que se resalta en los cánones ${ }^{39}$. No es evidente, en cambio, que estas discusiones se prolongaran. Nuestra impresión de que se estaban desarrollando querellas o que había alguna controversia sobre temas 'semipelagianos', es decir, sobre la predestinación o sobre el libre albedrío en la Iglesia hispana con posterioridad al 711, depende de la afirmación de Adriano $I^{40}$. Llama la atención que las

36 Prudencio. Peristephanon, IV, 45s (Thomson, H. J. (ed.). Prudentius. Cambridge, Mass.: Harvard University Press, 1953, vol. II). Gams, Pius Bonifacius. Die Kirchengeschichte von Spanien. Regensburg: Verlag von Georg Joseph Manz, 1864, vol. II, p. 313. Eugenio de Toledo nombró a un Casiano mártir zaragozano entre los venerados en la basílica de los dieciocho mártires (Carmen, 9, 15; Vollmer (ed.). $M G H, A A$, 14, Berlin, 1905, pp. 239ss).

37 Hefele había señalado una lectura semipelagiana, aunque centrándola en la idea de la predestinación (Hefele, Histoire des Conciles d'après les documents originaux, vol. III, pt. 2, p. 991). Rivera Recio, que recoge estas propuestas sobre el origen y significado del término, no se pronuncia (El adopcionismo en España, pp. 36ss y 45ss). En realidad, no entra a analizar la cuestión.

38 Solemos leer la Collatio, 13 como una respuesta crítica al De correptione et gratia (STEWART, Columba. Cassian the Monk. Oxford: Oxford University Press, 1998, pp. 20ss y 78ss). Sobre el debate, OGLIARI, Donato. Gratia et Certamen: The Relationship between Grace and Free Will in the Discussion of Augustine with the so-called Semi-Pelagians. Leuven: Leuven University Press, 2003, esp. pp. 265ss.

39 Las actas en Gaudemet, Jean y Basdevant, Brigitte. Les canons des conciles mérovingiens (VI -VIT siècles). Paris: Éditions du Cerf, 1989, Sources Chrétiennes, 353. Sobre las propuestas conciliares, CAPpuYns, M. «L'origine des “Capitula” d'Orange 529». Recherches de Théologie Ancienne et Médiévale, 1934, vol. 6, pp. 121-142.

40 Illud autem quod alii ex ipsis dicunt, quod praedestinatio ad vitam, sive ad mortem, in Dei sit potestate... Alii iterum dicunt, ut quid rogamus Deum ne vincamur tentatione, quod in nostra est potestate, quasi libertate arbitrii (Ep. 95). Al P. Ángel C. Vega (VegA, Ángel C. (ed.). España Sagrada, t. LIII-LIV. Madrid: Maestre, 1961, p. 314) ya le pareció «verdaderamente extraño» este predestinacionismo que emerge de sopetón. 
referencias a la gracia y la predestinación se encuentran más en las noticias que provienen de la correspondencia papal que del resto de nuestras fuentes. Es Adriano el que sostiene que hay quienes mantienen ideas propias de una absoluta predestinación ${ }^{41}$, pero también de lo contrario, aunque no dice quién afirmaba cada propuesta. Las críticas del concilio cordobés no apuntan en esta dirección y tampoco parece que haya insistencia por parte de Elipando sobre el asunto. Hefele supuso que Migecio sostendría algunas propuestas semipelagianas, pero no acaba de perfilarlas y parece que la base de la acusación es precisamente la interpretación que hace de la calificación del 'casianismo' que le asignaron sus condenadores en lo que constituye una argumentación circular. No parece tampoco que Elipando mantuviera posiciones semipelagianas. Si acaso, cabe ver en alguna alusión de pasada una perspectiva agustiniana $^{42}$. No obstante, sí observamos algunos elementos relacionados con el debate pelagianista que pudieron estar presentes. Advertimos la vigencia de alguna parte de esta polémica, pero bajo la forma de la discusión sobre la inpeccantia, pero parece tener más que ver con el rigorismo.

Vega ya destacó algunos precedentes para las palabras del papa sobre la predestinación y el libre albedrío. Adriano I estaba acudiendo a fragmentos de las Sentencias de Isidoro de Sevilla, en donde el obispo distingue quienes estarían destinados ad requiem de los réprobos abocados ad mortem ${ }^{43}$. Estas opiniones serían discutidas por otros, pues en la carta romana se señalan unas percepciones opuestas, es decir, pelagianas, que tendrían ese mismo u otro impreciso grupo. En definitiva, quizá las acusaciones tienen más que ver con una reconstrucción de las posturas del pelagianismo que de un efectivo debate sobre la predestinación y la gracia. Otra cosa es la vigencia de la controversia sobre la posibilidad de vivir sin pecado.

En el texto del concilio del 839, los obispos hispanos afirman que fue un tal Casiano el fundador del colectivo disidente. En efecto, los conciliares señalan que el auctor eorum fue un tal Casiano, quien parece haber vivido en un tiempo relativamente próximo, pero que quizá entonces ya había fallecido. Dada la relativa frecuencia de este nombre latino, hemos de suponer, como sugiere la propia acta conciliar, que hubo un individuo llamado así, probablemente no hispano, pues se afirma que algunos han llegado por $\operatorname{mar}^{44}$, que difundió en tierras de la Bética unas ciertas posiciones que fueron equiparadas con las propugnadas por Migecio contemporáneamente o algunos pocos años antes. Migecio era definido como el magister de todos ellos, pero el nombre con el que acaban siendo conocidos, el de casianos o casianistas, proviene de este otro personaje. La asimilación dejaba en el aire la ortodoxia del

41 El desarrollo de la praedestinatio ad vitam sive ad mortem se produce más bien en Gotescalco a partir de mediados del siglo ix. No hay referencia a estos problemas en el concilio de Frankfurt, sino que hay que esperar hasta el de Maguncia en 829. La frase recogida por Adriano y la manifestada por Gotescalco en su Confessio brevior (Lамвот, Cyrille (ed.). Oeuvres théologiques et grammaticales de Godescalc d'Orbais. Louvain: Spicilegium Sacrum Lovaniense, 1945, p. 54), proceden de Isidoro.

42 En su carta a Migecio se recalca que es la gracia y no la naturaleza la que ayuda a alcanzar la santidad: per gratiam adquirimus sanctitatem. Obviamente es un manifiesto a favor del papel de la gracia (Ep., I, 10). También se refiere que el conocimiento de la fe ha llegado a todas las gentes ad uitam predestinati (I, 13). Se subraya, pues, la difusión de la fe a todos los pueblos que están llamados a la vida, pero no parece que se extraiga de ello una afirmación sobre la predestinación de los elegidos.

43 Sent., VI, 2 (Cazier, P. (ed.). Isidori Hispalensis Sententiae. CCSL-111. Turnholt: Brepols, 1998); Vega, España Sagrada, t. LIII-LIV, pp. 317ss.

${ }_{44}$ Concilio, 1 (GIL (ed.), Corpus, I, pp. 135s): in littore maris ingressi sunt... 
(FIN DEL SIGLO VIII - PRINCIPIO DEL IX)

AMANCIO ISLA FREZ

grupo, pues cabía adjudicar a todos el estrafalario pensamiento trinitario ya pergeñado, si bien ya veremos cómo lo más relevante del debate fueron otras consideraciones.

\section{LOS DEBATES IN SITU}

Por su parte, la información del papado procedía de la que enviaban Égila y Juan, y es probable que estos reforzaran los problemas existentes en medios hispanos a los que ellos - de eso se trataba- con su actividad acabarían poniendo fin. Así, pudieron remitir información llamativa con alguna frase sugerente de Isidoro o sobre algún problema sobre la data de la celebración de la Pascua, un asunto sobre el que se había actuado, pues sabemos que provocó que Juan, un diácono toledano experto en temas escriturísticos, escribiera años antes una carta a los de Sevilla, en donde se había considerado el problema ${ }^{45}$. Es probable que esta disputa sobre la Pascua se produjera ya frente a los migecianos, pues Elipando en su carta a Fidel recuerda cómo hacía años había solventado estas cuestiones con los de esta ciudad, algunos de los cuales es posible que reclamaran ante el metropolitano de Toledo. Parece que la presencia de los migecianos se concentraba en el área hispalense, pero ni siquiera es completamente seguro que fueran ellos quienes sostuvieran modos no hispanos de calcular la Pascua ${ }^{46}$. Esta cuestión se redimensionó en las cartas de Adriano y se convirtió en un problema novedoso y decisivo, si hemos de aceptar al pie de la letra lo sostenido desde Roma.

Por otro lado, en las misivas cruzadas entre el papa y sus enviados aparece una larga serie de usos peculiares que se presentan como generalizados y que son respondidos desde Roma con la afirmación de que las traditiones de la recta fe residen en las prácticas que se desarrollan en la que es la caput ecclesiarum ${ }^{47}$. Estos usos, así presentados, dan una imagen que es la que el papado sostiene, a pesar de las dudas que ya tiene sobre la actitud y la ortodoxia de sus enviados a Hispania. Creemos que las informaciones que se enviaban desde la Península Ibérica tendían a exacerbar y a generalizar los problemas prescindiendo de matices ${ }^{48}$. En función de la magnitud de esas dificultades y lo abultado del error se hacía más necesaria y urgente esa misión que dirigía Égila, mientras que, algo más tarde, Adriano reclamaba

45 Propter Pascas erroneas (Anónimo mozárabe, 75. Gil (ed.), Corpus, I). La tradición hispana era celebrar la Pascua con arreglo a los ciclos de Dionisio el Exiguo o alejandrinos, que diferían de la práctica occidental y romana, como atestigua Gregorio de Tours. Historia Francorum, V, 17 y X, 23. KRUsCH, Bruno (ed). MGH. SRMerov. I, Hannover, 1937. Sobre estos usos hispanos, Gómez Pallarés, Joan. «El cómputo eclesiástico en la España de la escritura visigótica a través de sus manuscritos y textos». Miscellània en homenatge al P. Agustí Altisent. Tarragona: Diputació de Tarragona, 1991, pp. 461-468. Cordiolani, Alfred. «Textos de cómputo español del siglo vi. El 'prologus Cyrilli'». Hispania Sacra, 1956, vol. 9, pp. 127-139.

46 Ego et ceteri fratres mei in Ispalitanis tanto tempore diiudicauimus... tam in festis Pascalium quam in ceteris erroribus Migetianorum (Ep. III, Ad Fidelem, p. 81).

47 El concepto fue usado por el papa en su carta a Constantino VI y la emperatriz Irene (LAMBERz, Erich (ed.). Acta Conciliorvm Oecvmenicorvm. III. Concilium universale Nicaenum II. Concilii actiones I-III. Berlin-New York: De Gruyter, 2008, p. 121). En ella se subrayan los planteamientos de la primacía romana: la apostolicidad, Pedro, como princeps apostolorum, la potestas romana, la definición de la ortodoxia...

48 De un modo similar a lo realizado por los corresponsales que cruzaron cartas con el papado, como el obispo Juan que escribió a Hormisdas († 523) dibujando un penoso estado que motiva la reconvención papal (Epp., 24 y 25. PL, 63, cols. 421ss) o las quejas que generaron las respuestas de Siricio († 399) a Eumerio. 
alguna actuación por parte de la imprecisa jerarquía ortodoxa que pudiera existir en la zona. La llamada del papa reflejaba las dificultades para alcanzar sus objetivos.

Vamos a intentar presentar cómo vieron a estos disidentes, migecianos y casianistas, quienes los conocieron mejor, aquellos hispanos que convivieron con ellos. Es verdad que nuestras fuentes al respecto son críticas y condenatorias del movimiento. Aún puede decirse más, a menudo buscan ridiculizar al adversario, en lo que constituye el procedimiento habitual en este tipo de polémicas, y es fácil que exageraran o forzaran algunas de sus ideas. No se trata solo de seńalar que las opiniones reseñadas por los opositores puedan no corresponder al núcleo de las sostenidas por el colectivo sometido a escrutinio, además es que las críticas pueden tener perfiles menos evidentes que afectan también a quienes los proyectan. Una heterodoxia precisa de una ortodoxia que la defina, es decir, calificar a una corriente como herética exige que la otra se proclame ortodoxa, mientras que, por otro lado, ambas versiones quedan perfiladas por los elementos que aparecen en el debate. Con todo, pensamos que la manera más firme para dar algunas pinceladas sobre sus propuestas ha de partir de este ambiente más cercano.

El movimiento migeciano había generado un primer sínodo que se reunió quizá en 782 o muy poco después. El asunto, tratado luego por Elipando, no se aquietó. El tema es relevante y muestra las dificultades operativas de la Iglesia. Sabemos que cuestiones próximas fueron consideradas otra vez en un concilio de la Iglesia hispana reunido en 839, en donde se condenó a un colectivo que merece las mismas etiquetas generales. Merced a este nuevo concilio se advierte que algunos grupos discrepantes permanecían en la Bética, unos colectivos que eran percibidos como continuadores de aquellos combatidos por Elipando. La asamblea se celebró en Córdoba, siendo presidida por el metropolitano de Toledo, Vistremiro, y acudieron a la misma los de Sevilla y Mérida, más otros cinco obispos de la Bética. En las actas conciliares se acusa a este colectivo de diversos errores y, como era habitual, se los asocia a las herejías acreditadas desde antiguo. Partiremos de estas etiquetas para perfilar algunos de los rasgos de los casianistas, obviamente porque creemos que estas caracterizaciones no eran lanzadas al azar, sino que constituían una forma un tanto sofisticada de trazar la red en la que se insertaba esa corriente u opinión. Por otro lado, acudimos a las actas de este concilio, porque, como iremos viendo, se desarrolla en ellas una tarea de caracterización y condena de las propuestas migecianas.

Hemos de pensar que tanto el sínodo del 782 como el concilio que se reúne en la capital del emirato en 839 hubieron de contar con la aquiescencia de los omeyas. En el material conservado no hay referencia alguna al poder político, pero es difícil suponer que todos estos eclesiásticos viajaran sin salvoconductos y sin el conocimiento de las autoridades. Estamos, por tanto, ante una organización que reclamó del poder la posibilidad de manifestarse como tal y de actuar contra un colectivo minoritario, refractario a esa autoridad emanada de la estructura tradicional. Sin embargo, no parece que sus disposiciones produjeran medidas contundentes ante la pasividad del poder islámico. No obstante, la obra escrita y su difusión, más las propias reuniones del clero, hubieron de señalar la alteridad del colectivo casianista. Se ponía de relieve la capacidad de respuesta eclesiástica y su afirmación de ortodoxia ${ }^{49}$, pero

49 Sobre la constitución de la ortodoxia tengo en cuenta la sugerencia de CAmeron, Averil. «How to read Heresiology». Journal of Medieval and Early Modern Studies, 2003, vol. 33, n. o 3, pp. 471-492. También 
al tiempo quedaban al descubierto sus debilidades: no había un poder político interesado en implementar con rapidez sus disposiciones. Con todo, la sola amenaza de que la iglesia de los disidentes pudiera ser destruida en caso de perseverar en sus postulados, como dictaminó el concilio cordobés, exigiría una abierta actividad violenta y algún plácet del emirato que los obispos creyeron que les sería factible recabar.

El concilio acusa a los Casiani de ser semejantes a los jovinianos y a los simoníacos. Esta última nota no tiene que ver con la compraventa de las dignidades eclesiásticas, ni siquiera con alguna discusión sobre la capacidad de obrar milagros. Algunos testimonios antiguos difundieron la noticia de que Simón Mago compartió su actividad y el lecho con una mujer llamada Helena de Samaria, aunque, al parecer, ese comportamiento pudo no ser plenamente público y quedar oculto a los demás. En cualquier caso, la leyenda era suficientemente conocida y completaba la caracterización aceptada generalmente sobre el personaje que se había enfrentado a los apóstoles, de manera que en este contexto hemos de entender que nuestro bien informado heresiólogo se refiere al comportamiento impropio y libidinoso de Simón ${ }^{50}$. Es posible, además, que se buscara llamar la atención sobre ese perfil de Simón como impropio y engañoso hombre de religión que se atrevió, además, a rivalizar con los apóstoles. La noticia en la carta de los obispos hispanos sobre una muliercula en el entorno de Migecio parece apuntar en este mismo sentido para dejar en el aire algún comportamiento inadecuado por parte de quien se consideraba el líder de la secta ${ }^{51}$.

La caracterización, como hemos señalado, afirma que son comparables a los jovinianos. Joviniano en los últimos años del siglo iv había resaltado la importancia radical del bautismo. Como bautizados, los cristianos quedaban equiparados, por lo que de algún modo se aminoraba el valor asignado al ascetismo, obviamente también al papel de la continencia sexual. Joviniano había subrayado que, en tanto que cristianos bautizados, una casada no era inferior a una virgen. Siguiendo la práctica habitual, el argumento que desde luego implicaba una cierta indulgencia con la actividad sexual fue transformado en la propuesta que correspondería a una mente depravada, una mens prava $^{52}$, que propiciaría la gula y toleraría el sexo. Presentado como el Epicurus Christianorum ${ }^{53}$, sus opiniones fueron reconvertidas en

Shaw, Brent. "African Christianity: Disputes, Definitions, and 'Donatists'». En Greenshields, Malcolm R. y Robinson, Thomas Arthur (eds.). Orthodoxy and Heresy in Religious Movements: Discipline and Dissent. Lewiston, N.Y.: Edwin Mellen Press, 1992, pp. 5-34. Además a Barbero, que subrayaba cómo la jerarquía de fines del siglo IV etiquetaba como herejes a quienes se alejaban de su disciplina (BARBERo, Abilio. "El priscilianismo, ¿herejía o movimiento social?». En Conflictos y estructuras sociales en la Hispania antigua. Madrid: Akal, 1986, p. 89.

50 Epifanio de Salamina, Panarion, 21, 2, 2; Williams, Frank (ed.). The Panarion of Epiphanius of Salamis Book I. Leiden: Brill, 2009, p. 62. Agustín señala que se trataba de una meretriz llamada Minerva (De haeresibus, I. PL. 42, col. 25); también Jerónimo apunta estas prácticas, Ep. 133 (Ad Ctesiphontem). HiLBERG (ed.). Viena-Leipzig: CSEL-56, 1918, pp. 247ss.

51 Ep. IV, 5. Gil (ed.), Corpus. I, p. 92.

52 Según Jerónimo serían: impugnare uirginitatem, odisse pudicitiam (1, 10). Vid., HunTER, David. Marriage, Celibacy, and Heresy in Ancient Christianity: The Jovinianist Controversy. Oxford: Oxford University Press, 2009.

53 Adversus Jovinianum, I, 1 y II, 36 (PL, 23, cols. 221 y 349); in coitu et saturitate Epicurus est (II, 21, col., 329). Más comedido, Agustín. De haeresibus, LXXXII, PL, 42, col. 45ss. 
una invitación a la promiscuidad. Por tanto, con estos dos calificativos cualquier persona familiarizada con la panoplia herética sabía dónde situar a este colectivo.

El paralelismo sugiere una relajación moral en materia sexual que es precisada en el sentido de que estos colectivos promovían el matrimonio con parientes o con personas de otra fe. Hemos de pensar, probablemente, que es este último punto el núcleo central dentro de esta sección. Suponemos que estos matrimonios que se señalan afectaban fundamentalmente a cristianas que se unían a musulmanes. El cristianismo había aceptado la existencia de uniones mixtas (1 Cor., 7, 12-16; 1 Pet., 3, 1-6) en la idea de que podían favorecer las conversiones $^{54}$, pero los recelos sobre las mismas también se desarrollaron. Ya había manifestado críticas Tertuliano y otras se fueron sumando, incluida la prohibición de estas uniones mixtas en el concilio de Elvira ${ }^{55}$. De hecho, no se trata de aceptar un matrimonio ya existente, como el que motivaba la Carta a los corintios, sino de diseñar uno con un varón de otra fe ante el que la mujer quedaba en situación de vulnerabilidad. La decisión de estos colectivos parece revelar una fijación con la inicial aceptación de estas uniones que, sin embargo, suscitaban todas las prevenciones entre los demás. Resumiendo, sugerimos la posibilidad de que los casianistas fueran partidarios de seguir las indicaciones paulinas y petrinas más las recomendaciones de Jerónimo con respecto a aceptar los matrimonios mixtos ${ }^{56}$, mientras que los obispos del concilio eran reacios ante este tipo de uniones. Es probable que influyera

54 MacDonald, Margaret. "Early Christian women married to unbelievers». Studies in Religion/ Sciences Religieuses, 1990, vol. 19, n. ${ }^{\circ}$, pp. 221-234. En la propuesta paulina se ponía en valor la fe de la descendencia y el caso de la mártir Perpetua, fruto de un matrimonio mixto, que a su vez asegura una formación cristiana para su hija (Nathan, Geoffrey S. The Family in Late Antiquity: The rise of Christianity and the endurance of tradition. London-New York: Routledge, 2000, p. 51) podía servir como modelo, como también lo sería Agustín de Hipona, otro hijo de una unión mixta. Para referirse a estos matrimonios el texto emplea connubium. Los recelos fueron crecientes; sobre ellos, MacDonald, Margaret. "Was Celsus Right? The Role of Women in the Expansion of Early Christianity». En Balch, David L. y Osıek, Carolyn (eds.). Early Christian Families in Context. An Interdisciplinary Dialogue. Grand Rapids: Eerdmans, 2003, p. 179. Por otro lado, la tradición visigoda fijaba el incesto en el sexto grado -usque ad sextum generis gradum (LI, III, 5,1; ZEUMER (ed.). MGH, Leges; Etym., IX, 6, 29)-, quizá resultaba más estricto que en otras tradiciones, pero, en cualquier caso, es probable que las contaran de otro modo, no por grados, sino por generaciones (vid., Jong, Mayke de. "An unsolved riddle: early medieval incest legislation». En Wood, Ian (ed.). Franks and Alamanni in the Merovingian period: an ethnographic perspective. Woodbridge: Boydell Press, 1998, pp. 107-140).

55 Raepsaet-Charlier, Marie-Thérèse. "Tertullien et la législation des mariages inégaux». Revue Internationale des Droits de l'Antiquité, 1982, vol. 29, pp. 253-263. El concilio de Elvira prohíbe en su c. 15 el matrimonio de jóvenes mujeres con quien proviene de la gentilidad, en base a la amenaza de que abandonaran el cristianismo (Martínez Díez, Gonzalo y Rodríguez, Félix. La colección canónica hispana. IV. Concilios galos. Concilios hispanos. Madrid: Consejo Superior de Investigaciones Científicas, 1984, p. 247).

56 Se ha destacado su Ep., 107 (Hilberg, I. (ed.). Viena-Leipzig: CSEL-55, 1912), alabando a Laeta, hija de un matrimonio mixto, que ha convertido a su marido, una carta que parte de la cita de la Epístola a los corintios. Peter Brown había señalado la importancia de estas uniones (Brown, Peter. "Aspects of the Christianization of the Roman Aristocracy». The Journal of Roman Studies, 1961, vol. 51, pp. 1-11). Allí retoma la afirmación de Agustín (De fide et operibus, XIX, 35; ZychA, J. (ed.). Viena: CSEL-41, 1900, pp. 80s) de que, si en el pasado Cipriano de Cartago había considerado inaceptable que los cristianos se casaran con gentiles, ahora no se cree pecado, pues no hay nada preceptuado contra ello en las Escrituras. Hay que destacar la crítica de Salzman de esta argumentación, ahora al alcance en SAlzman, Michele Renee. The Making of a Christian Aristocracy. Social and Religious Change in the Western Roman Empire. Cambridge: Harvard University Press, 2002, pp. 144 ss. 
sobre ellos el dictamen de Elvira, aunque quizá lo reforzaban por la experiencia directa de las consecuencias de los casamientos contraídos entre cristianas y musulmanes. En cualquier caso, los conciliares presentaron esta opción de los casianistas como la apertura e, incluso, la promoción de un comportamiento libidinoso.

Son también maniqueos. La afirmación viene a dar color a la renuencia de estos grupos a compartir alimento con los gentiles. La asociación con los maniqueos es, pues, en principio tangencial. Los maniqueos eran asociados tradicionalmente a los grandes ayunos y a cierta aversión general a la carne, en tanto que afirmaban que provenía de la impureza y la oscuridad y que su consumo las reforzaba, a lo que sus oponentes respondían con la afirmación paulina (Rom. 14, 20) de que todo lo hecho por Dios era limpio ${ }^{57}$. Ayunaban los domingos y los lunes y en algunas festividades cristianas, entre ellas la Navidad ${ }^{58}$. De lo que se acusa a los casianos es de realizar el ayuno los viernes de quizá todo el adviento o de la semana de la Navidad. Mientras que ayunar los viernes era una práctica consolidada desde la época de la Didache ${ }^{59}$, estos ayunos debían anularse si coincidían con grandes conmemoraciones y muy especialmente en la Navidad ${ }^{60}$. Es evidente que los aquí condenados no estaban en las coordenadas más plenas del maniqueísmo, sino que quizá estaban desarrollando prácticas no tradicionales en la Iglesia hispana. Se trataba así, otra vez, de elementos no doctrinales que suscitaron una encendida respuesta ahora por parte del concilio. En cualquier caso, la comparación con los maniqueos podía resultar efectiva también en cuanto a las prácticas alimentarias de los criticados, más aún porque aquellos observaban una ritualidad específica en la recolección y preparación de los alimentos que también haría complicada su relación con otros comensales. Sea como fuere, la imagen aportada por el concilio venía a asociar a los casianistas con una secta herética bien conocida y denostada.

En la carta de Elipando señalando los errores de Migecio se acude también al tema de la consideración de los alimentos. El metropolitano resalta cómo Migecio afirma que

57 De moribus ecclesiae catholicae, II, 14 (34-35); PL, 32. Los priscilianistas habían sido acusados de maniqueos por parecidos motivos (Vigilio. Epistola ad Profuturum, 1. Mansi, (ed.). Sacrorum conciliorum. IX, col. 30).

58 Gardner, Iain y Lieu, Samuel N. C. (eds.). Manichaean Texts from the Roman Empire. Cambridge: Cambridge University Press, 2004, no 30, p. 123.

59 Didache, 8, 1. JefFord, Clayton N. (trad.). Didache. The teaching of the twelve apostles. Salem, OR: Polebridge Press, 2013, p. 34.

${ }_{60}$ En Roma se había desarrollado un ayuno de Navidad realizado desde mediados de noviembre, afectando a los miércoles, los viernes y la víspera de la Navidad. El ayuno navideńo es mencionado por Filastrio (De haeresibus, 149. Marx, F. (ed.). Diversarum hereseom liber. Viena: CSEL-38, 1898, pp. 120ss) por lo que sabemos que ya estaba difundido en el siglo iv. Sin embargo, los ayunos del día de Navidad habían sido condenados por el I concilio de Braga como propios del priscilianismo y otras herejías, como las de los gnósticos y maniqueos (cap. IV; VIVEs, José (ed). Concilios visigóticos e hispano-romanos. Barcelona-Madrid: Consejo Superior de Investigaciones Científicas, 1963, pp. 67ss). La práctica de ayunos este día está acreditada también por la correspondencia de Toribio al papa León (PL, 54, col. 632). El Concilio de Macon del 581 (canon 9; MGH, Concilia, I, p. 157) revela su uso en Occidente. El concilio de Girona del 511 había instituido un ayuno en la primera semana de noviembre (canon 3) y el IV concilio de Toledo colocaba el ayuno en Año Nuevo (canon 11; Martínez Díez y Rodríguez, La colección canónica hispana. IV, pp. 285ss y $V$, pp. $199 \mathrm{ss}$ ), pero los calendarios establecen el dos de enero un ieiunum in caput anni (FÉrotin, Marius. Le Liber Ordinum en usage dans l'Église wisigothique et mozarabe d'Espagne du cinquième au onzième siècle. Roma: Edizioni Liturgiche, 1996, pp. 450ss). 
la comida de los infieles es impura y que no ha de ser ingerida por los cristianos. Con este aserto se está recalcando el punto de vista que sus oponentes tenían de la secta. Los maniqueos entendían que el consumo de alimentos, y específicamente de algunos de ellos, afectaba (negativamente) al que los tomaba, haciéndolos cada vez más materiales y oscuros $^{61}$. Frente a la opinión del apóstol Pablo, que había insistido que con respecto a la comida el único asunto a considerar habría de ser si el consumo de algún producto podía molestar a un comensal y que no había alimentos impuros, se presentaba esta actitud de los casianistas como contraria a las prácticas cristianas ortodoxas. Los maniqueos, por su parte, distinguían a unos electi, elite superior del grupo, más santos y excelentes, que no tocaban ni preparaban esos alimentos que comen que son dispuestos por los otros miembros del colectivo, los oyentes ${ }^{62}$.

Esta acusación es la que explica la presencia en la carta de Adriano de referencias a las prácticas alimentarias y a qué posición tomar con respecto a la ingesta de carne de animales ahogados, a la sangre de los animales y a la carne de cerdo. Adriano insistía en la prohibición del consumo de sangre o de la carne de animales ahogados, lo cual, por otra parte, le aproximaba a la dieta islámica que prohíbe comer carne ahogada o muerta sin ser propiamente degollada y desangrada. Adriano en su declaración seguía tradiciones antiguas $^{63}$, que, sin embargo, se distanciaban de las recomendaciones paulinas y de las manifestaciones de Isidoro de Sevilla ${ }^{64}$. Es posible que estas preocupaciones solo fueran el extremo al que podía conducir la admisión de la toma de cualquier producto comestible, pues no parece haber habido compulsión de ningún tipo para consumir la carne de los animales ahogados. Sin embargo, en las noticias provenientes de Elipando o del concilio el tema parece estar en relación con compartir comida con los no cristianos y -se entiende sobre todo en el concilio- tomar sus alimentos. Se trata, sobre todo, de una cuestión de convivialidad y no de incluir en la dieta tipos de carne, específicamente la que conserva más sangre o la de animales sacrificados al modo islámico. Las cartas cruzadas con Roma muestran una percepción papal contraria a acceder a estos alimentos de los gentiles, aunque su mensaje se dispersa, pues al tiempo se opone a la ingesta de carnes con alto contenido de sangre.

El asunto vuelve a combinarse con el tema general de la santidad. Migecianos y casianistas propugnaban que no debería haber relación con los no cristianos en momentos señalados del anudamiento y desarrollo de relaciones humanas. No era apropiado compartir alimentos con ellos, lo que constituía una seria traba al mantenimiento de lazos sociales. Estos colectivos que se proclamaban santos, según Elipando, debieron entender como concesión impropia que otros cristianos mantuvieran banquetes y se relacionaran

61 Ep., I, 11.

62 De haeresibus, XLI, PL, 42, col. 35.

63 Así en el concilio de Gangra (canon 2), pero que quedaba matizado en la Hispana. Sobre el asunto, Vega, España Sagrada, p. 309. Sobre las prevenciones al consumo de sangre y de carne de animales suffocati, Tertuliano. Apologeticum, 9, 13. Dekkers, E. (ed.), Tertulliani Opera. Turnholt: Brepols CCSL-1, 1954, p. 104). La Iglesia primitiva mantuvo algunas prescripciones judaicas, pero la tradición culinaria romana aceptaba el consumo de sangre en diversas formas, como los botuli mencionados por el propio Tertuliano.

64 Isidoro de Sevilla. De fide catholica ex vetere et novo testamento contra Judaeos, XVIII, 2. PL, 83, col. 527; Sent., II, 44, 9. 
en la mesa con estos colectivos. Al tiempo, siguiendo unas coordenadas bien enraizadas, apuntaron críticas sobre la naturaleza de los manjares a consumir que es el tema sobre el que incide Elipando.

En la carta que Saúl de Córdoba escribió a Álvaro, algo después de mediar el siglo IX, le insta a que dé más explicaciones o que caracterice mejor a quienes destaca por su rigidez, si son estos migecianos, luciferianos o donatistas ${ }^{65}$. Estos luciferianos son los discípulos de Lucifer de Cagliari, un escritor y polemista antiarriano que criticó implacablemente la actuación del emperador Constancio II y toda dinámica de reconciliación con los no niceístas. Luciferianos y donatistas habían implicado en su momento una actitud de rechazo pleno ante aquellos que hubieran caído temporalmente en la herejía, incluso frente a los que hubieran contemporizado con ella, de manera que quienes siendo sacerdotes $\mathrm{u}$ obispos se hubieran rendido ante la herejía o ante posiciones acomodaticias perderían su condición. Hemos de suponer que también los migecianos se aislaban no solo de los musulmanes, probablemente de los otros cristianos.

La referencia concuerda con el concepto que está presente en la carta de Elipando a Migecio y en cierto modo en el concilio. En la carta Elipando les critica su pretensión de ser santos. En su argumentación resulta peculiar que no emplee las disposiciones de los concilios africanos que habían condenado similar empeño de los donatistas. Elipando se remite al mensaje paulino y tampoco incide en las reflexiones agustinianas sobre la condición humana pecadora. La larga cita en la que se apoya el de Toledo proviene del Liber ecclesiasticorum dogmata, un tratado atribuido a Genadio de Marsella ampliamente utilizado en la polémica ${ }^{66}$. Es decir, ni Elipando ni el concilio situaron a los casianistas en el debate antipelagiano. Sin embargo, eran conscientes de sus pretensiones de vivir en santidad. De hecho, ambas obras dan a esta propuesta una importancia singular. En la carta Elipando sostiene que los migecianos se postulan santos, lo que entiende como una afirmación contraria a las Escrituras. Algo similar aparecerá en el concilio: una acusación que parece indicar la voluntad de este colectivo y de su jerarquía de pertenecer a esta categoría, mientras que otros no lo son. Es este el alegato fundamental: la proclamación de la santidad por parte de migecianos y casianistas implica la negación de la misma para los otros. Son la actitud y las formas de vida las que permiten afirmarla (socialmente) para unos, mientras que la consecuencia es evidente para quienes no mantienen esas conductas.

Sobre la posibilidad de ser santo, a veces definida como impecantia, ya se había desarrollado una amplia polémica centrada en la crítica a Pelagio y a sus opiniones. El obispo toledano recuerda en este contexto la indicación de Gregorio Magno, quien advierte que se asimila al demonio (el ángel apóstata) quien, siendo humano, desprecia ser como los

65 Plane nescio, quos salsuginosas asseritis et prope Migentianos, Donatistas et Luciferianos notatis (Ep., 12, 2; Gil (ed.). El sentido de salsuginosus en MADOz, José. Epistolario de Álvaro de Córdoba. Madrid: Consejo Superior de Investigaciones Científicas, 1947, p. 204.

${ }_{66}$ CPL 958. Lo estudia y edita, Turner, C. H. «The Liber ecclesiasticorum dogmatum attributed to Gennadius». The Journal of Theological Studies, 1905, vol. VII, n. ${ }^{\circ} 25$, pp. 78-99. Era una obra bien conocida en época visigoda, Martín Iglesias, José Carlos. "La biblioteca cristiana de los padres hispanovisigodos (siglos vI-VII)». Veleia, 2013, vol. 30, p. 268. 
demás ${ }^{67}$. En la idea de que el hombre no puede alcanzar la santidad Elipando se aproximaba a las críticas que los defensores de Agustín, como Próspero de Aquitania, habían hecho a Casiano ${ }^{68}$. El contexto para el obispo toledano es claramente el de la soberbia que lleva a la exaltación y, frente a ella, cabe promover la humildad que obviamente implica el sometimiento. Esta línea argumentativa nos lleva al otro punto dominante de las propuestas migecianas, de acuerdo con la epístola de Elipando. Esta santidad y esta sobreelevación del colectivo sobre el resto de los cristianos se justifican por su relación con Roma. Así se fundamentaría la santidad de su jerarquía, el rigor de sus fieles y el distanciamiento con respecto a los gentiles y presumiblemente a otros cristianos ${ }^{69}$. Sus críticos insistieron en su proximidad a diversas heterodoxias, pero aquí entraron a considerar algunos pormenores.

\section{El Mediterráneo, Roma y los carolingios}

Los migecianos creen en una Iglesia absque macula et ruga ${ }^{70}$. La percepción de la Iglesia sin tacha había estado presente durante el conflicto donatista y había sido combatida por Agustín, quien recordaba su condición mixta. Sin embargo, Agustín adjudica la santidad de la Iglesia a Pedro, quien ha recibido las llaves para atar y desatar ${ }^{71}$.

La cuestión parece haber girado en torno a que los migecianos afirmaban que la única Iglesia que podía definirse como santa era Roma. Así, seguían la pauta establecida por el concilio romano del año 382, cuyo contenido había sido insertado en el Decretum Gelasianum y se había convertido en un pilar fundamental del desarrollo de la primacía papal ${ }^{72}$. Además, los migecianos sostenían que solo Roma tiene la potestas Dei. Esta idea es apostillada por la aseveración de que es allí donde habita Cristo, in qua Christus

67 Regula pastoralis, II, 6. Judic, B. (ed.), pp. 202ss.

68 Vid., Hwang, Alexander Y. Intrepid lover of Perfect Grace: The Life and Thought of Prosper of Aquitaine. Washington, DC: The Catholic University of America Press, 2009, pp. 157ss.

69 El concilio señala que solo aceptaban las ordenaciones realizadas por Ágila, obispo de una imprecisa sede de Ementia, que puede ser mala transcripción de Emerita o, más probablemente, una desconocida. Si, como parece viable, es el mismo que el Égila de la misión franco-romana, tendríamos un nexo más que ligaría estas dinámicas (Collins, Roger. Caliphs and Kings: Spain, 796-1031. Oxford: Wiley-Blackwell, 2012, pp. 99ss) y reforzaría los recelos de la jerarquía hispana.

70 Ut exhiberet ipse sibi gloriosam Ecclesiam, non habentem maculam, aut rugam, aut aliquid hujusmodi, sed ut sit sancta et immaculata (Ephes., 5, 27).

71 Carola, Joseph. Augustine of Hippo: The Role of the Laity in Ecclesial Reconciliation. Roma: Editrice Pontificia Università Gregoriana, 2005, pp. 109ss. El debate donatista reforzó la posición de Roma como referencia última de la ortodoxia, bien manifestada en la Ep. 43 de Agustín. Más contenido sobre el tema, Markus, Robert A. Saeculum. History and society in the theology of St Augustine. Cambridge: Cambridge University Press, 2007, pp. 188ss. Cavadini relaciona esta postulada santidad casianista con la tradición donatista (Cavadini, The Last Christology of the West, p. 12).

72 Decretum Gelasianum, III, 3. Doвschüтz, Ernst von (ed.). Das Decretum Gelasianum de libris recipiendis et non recipiendis. Leipzig: Hinrichs, 1912, p. 7. Las coordenadas se muestran en la correspondencia de Adriano: Hanc ergo ecclesiis toto orbe diffusis velut capud suorum..., ideas también procedentes del canon 3 del concilio del 382. 
habitat ${ }^{73}$. De este modo confirmamos su referencia a la Iglesia. Parece que estamos ante un concepto que procede de la afirmación y del desarrollo del principio petrino que otorgaba a Roma una posición principal y que la señalaba como única instancia ligandi et solvendi. La Iglesia es por antonomasia la romana y es allí donde radica la autoridad ${ }^{74}$. Elipando no está de acuerdo con esa liquidación de las iglesias territorializadas. Su respuesta va en el sentido de postular la Iglesia como realidad universal y, por tanto, no única ni necesariamente romana: no discute lo establecido en Mat., 16, 18, pero sí pone en paralelo la condición católica-universal de la Iglesia. Frente a la propugnada superioridad romana, Elipando acude al argumento histórico de recordar al papa Liberio (352-366) y su sometimiento ante las presiones proarrianas ${ }^{75}$. Roma no puede ser el espacio de santidad que proponen los discordantes, pues a su frente ha estado un herético pro-arriano.

Las actas del concilio nos muestran un perfil similar, en tanto que parecen redactadas para definir y subsidiariamente condenar a los mismos colectivos, pero en realidad hay notables diferencias. La fundamental divergencia radica en que aquí no encontramos alusión alguna a un pensamiento trinitario que se aparte de la ortodoxia. El asunto no se menciona, por lo que entendemos que no tuvo ningún papel en esta fase del conflicto, a la vez que nos hace pensar que no constituía el núcleo de los planteamientos casianistas, sino que formó parte de alguna argumentación poco afortunada de Migecio. Sí encontramos otras precisiones. En primer lugar, se otorga al grupo, entre otros, el nombre de casianos y se les relaciona con diversas herejías, un paralelismo que, si nos viene resultando de alguna utilidad para precisar algunas de las propuestas, busca encuadrar a los divergentes en el bloque de los grandes condenados por la Iglesia. Además, se señala en primer lugar -lo que es un rasgo fundamental para destacar la relevancia que se le otorgaque el colectivo se afirma enviado desde Roma, trayendo unas traditiones que no son las aceptadas en la Península. Entre ellos se encuentra un obispo que no ha sido reclamado por ninguna comunidad para alguna sede existente y -se entiende- vacante, lo cual va en contra de las prácticas de la Iglesia universal. Los conciliares del 839 citan un canon del IV toledano que recoge la exigencia de que el nuevo obispo sea elegido por el clero y el pueblo de la ciudad y, además, remite a algunas indicaciones de Calcedonia sobre que no se designe clero absolutus, es decir, sin un lugar concreto en el que radicarse ${ }^{76}$. El asunto era, por tanto, que los disidentes se habían constituido como un grupo autónomo

73 Euquerio de Lyon la había empleado para remitirse a la Iglesia: Domus, anima in qua Christus habitat, vel Ecclesia (Formulae spiritalis intelligentiae, IX; Wотке (ed.). Viena: CSEL-31, 1894, p. 55). Cita muy bien traída, porque Euquerio está hablando de Jerusalem: Hierusalem ecclesia uel anima.

74 Sobre el desarrollo de este concepto desde época de León I puede verse el clásico de UlLMANN, Walter. "Leo I and the theme of papal primacy». The Journal of Theological Studies, 1960, vol. 11, n. ${ }^{\circ}$ 1, pp. 25-51; Wessel, Susan. Leo the Great and the Spiritual Rebuilding of a Universal Rome. Leiden-Boston: Brill, 2008; y Blaudeau, Philippe. «Narrating Papal Authority (440-530): The Adaptation of the Liber Pontificalis to the Apostolic See's developing Claims». En Dunn, Geoffrey D. (ed.). The Bishop of Rome in Late Antiquity. Farnham: Routledge, 2015, pp. 127-140.

75 Cediendo ante el emperador Constancio: in haereticam pravitatem subscribens (Jerónimo, Chron., s.a. 349. Helm, Rudolf (ed.). Die Chronik des Hieronymus. Leipzig, 1913, p. 237).

76 Quem nec clerus nec populus propriae ciuitatis elegit (canon 19; MARTínEz DíEz, Gonzalo y RodríGuez, Félix (eds.). La colección canónica hispana. V. Concilios hispanos. Madrid: Consejo Superior de Investigaciones Científicas, 1992, p. 209ss.). El canon 6 de Calcedonia condenaba los nombramientos clericales sin 
y que tenían su propio clero, habiendo ocupado o construido una iglesia al margen y por encima de las peticiones del entorno.

El concilio es muy consciente de que este es un tema central. Prácticas, como las ya referidas del ayuno de diciembre, venían a mostrar otros usos. Lo importante es que ante estas otras tradiciones se acude a un comportamiento que es el de la respuesta de la ortodoxia frente a la herejía. Quienes desarrollan esas propuestas son heréticos, a diferencia de quienes las critican que son los ortodoxos. En su error los casianos son comparables a la larga serie de movimientos heréticos que se han desarrollado a lo largo de la historia del cristianismo. Algo similar se deduce de la descripción del bautismo celebrado por los disidentes. Un sacramento que es practicado por estos escupiendo en la boca del neófito. Suponemos un malentendido o una exageración por parte de los conciliares y presumimos que el ritual seguía la práctica romana de humedecer con saliva la boca y las orejas de los que se bautizaban ${ }^{77}$. Mas este procedimiento que tenía un largo pasado y algún apoyo escriturístico (Marc., 7, 34) era presentado como una más de las alteridades que definían al colectivo.

La acusación de vigilancianos que figura en el concilio de 839 alude a los seguidores de Vigilancio, un escritor galo finalmente radicado en Calahorra en los últimos años del siglo IV y primeros del siguiente. El redactor de las actas no solo conocía de nombre la herejía, había leído a Jerónimo quien arremetió contra Vigilancio, llamándole por antífrasis Dormitantius $^{78}$. Es probable que la caracterización incida en la disposición contraria a las vigilias. Otros motivos del enfrentamiento eran la crítica de Vigilancio a la veneración de las reliquias, afirmando -en palabras de Jerónimo- que los partidarios de su culto habrían de denominarse y ser considerados como cinerarii o directamente idólatras; también se apunta alguna preferencia por parte de Vigilancio del matrimonio de los clérigos.

Esta negativa a prestar culto a las reliquias tuvo a principios del siglo IX un cierto desarrollo en medios carolingios debido a la crítica lanzada por Claudio de Turín ( $\dagger$ 827/828) sobre la veneración a las imágenes, pero, teniendo en cuenta la cronología de sus propuestas, cabe apuntar otras posibilidades para explicar el auge de estos debates ${ }^{79}$.

iglesia asignada (Martínez Díez, Gonzalo y Rodríguez, Félix. La colección canónica hispana. III. Concilios griegos y africanos. Madrid: Consejo Superior de Investigaciones Científicas, 1982, p. 252).

Sacramentario Gelasiano, 72: Inde saliva oris sui cum digito tangit nares et aures... (WILson, Henry A. The Gelasian Sacramentary: Liber sacramentorum Romanae Ecclesiae. Oxford: Clarendon, 1894, p. 114). Véase la descripción de Ambrosio de Milán de estos pormenores y de la voz Ephphetha que liga este detalle de la liturgia bautismal con la curación del sordomudo (Ambrosio de Milán, De sacramentis, I, 1, 2; FALler (ed.). Viena: CSEL-73, 1955, pp. 14s). La costumbre casianista de tomar la comunión en las manos, que condena el concilio (6, p. 139), puede ser un síntoma oriental, pues hay algún testimonio del desarrollo de esta práctica en Cirilo de Jerusalem o en Juan Damasceno y queda reflejada en el concilio Quinisexto (Louth, Andrew. St. John Damascene: Tradition and Originality in Byzantine Theology. Oxford: Oxford University Press, 2002, pp. 184s).

78 Jerónimo, Ep. 109, 1. La mención de los monstruosos hipocentauros de las actas cordobesas (6) recoge una nueva nota crítica de Jerónimo (Contra Vigilantium, I, 1; PL, 23, col. 337).

79 Claudio era crítico con cualquier culto que no fuera dirigido a Dios (Apologeticum, PL, 105, cols., 459 ss) y parece haber dudado de toda posibilidad intercesora de los santos, por lo que le criticará Dungal en sus Responsa (PL, 105, col. 472), afirmando que se los debe honrar (honorare) como santos hombres de Dios. Tampoco da la impresión de haber sido proclive a las propuestas petrinas, por lo que no parece que estuviera 
En cualquier caso, de las sugerencias de Claudio cabe derivar su puesta en duda de la capacidad de intermediación de los santos. Es probable que esta aversión al culto a las reliquias tenga que ver con planteamientos generales que ya habían dejado su huella en Constantinopla desde la primera mitad del siglo VIII $^{80}$. Aunque se están matizando las proporciones del rechazo oriental a las reliquias dentro del contexto general de la iconomaquia, claramente hubo renuencia a prestarles culto, por más que no quepa hablar de un diseño de eliminación de las mismas. Con todo, fuentes posteriores construirán esa política antirreliquias, poniendo de relieve que lo entendían como un desarrollo natural de lo que habían vivido ${ }^{81}$.

Contra las propuestas orientales los francos reunieron en 767 un concilio en Gentilly del que no se han conservado las actas ${ }^{82}$. Al hilo de estas reflexiones debió escribir Pipino al emperador, mandando una copia al papa, quien a su vez remitió al rey franco una misiva $^{83}$. De las cartas de Paulo I se hace evidente la crítica propter sanctam et orthodoxam fidem et venerandorum patrum piam traditionem, aunque no se precisa el contenido del distanciamiento ${ }^{84}$.

El concilio laterano del 769, una asamblea convocada por Esteban II que combatió las medidas de Constantino V, subrayó la importancia del culto a las reliquias, afirmando en uno de sus cánones que debían ser veneradas, también las de contacto ${ }^{85}$. En el concilio II de Nicea, reunido en 787 , se establece, frente a situaciones anteriores, que no

en la raíz de los planteamientos de los casianistas. Sobre esta polémica, BoureAu, Alain. «Les théologiens carolingiens devant les images religieuses. La conjoncture de 825». En Boespflug, François y Lossky, Nicolas (eds.). Nicée II, 787-1987. Paris: Éditions du Cerf, 1987, pp. 247-262. Sobre las reliquias, esp. pp. 252ss.

80 Dagron, Gilbert. "L'ombre d'un doute: L'hagiographie en question, $\mathrm{vI}^{\mathrm{e}}-\mathrm{XI}^{\mathrm{e}}$ siècle». Dumbarton Oaks Papers, 1992, vol. 46, pp. 59-68; Wortley, John T. «Icons and Relics». Greek, Roman, and Byzantine Studies, 2002-2003, vol. 43, pp. 161-174. Hay alguna noticia de actividad contra las reliquias en época de León III (Gerö, Stephen. «Notes on Byzantine iconoclasm in the eighth century». Byzantion, 1974, vol. 44, n. ${ }^{\circ}$, pp. 23-42, esp. pp. 26ss).

${ }_{81}$ Los isáuricos negaron la capacidad intercesora de las reliquias y consagraron iglesias sin ellas (Auzépy, Marie-France. «Les Isauriens et l'espace sacré: L'église et les reliques». En Kaplan, Michel (ed.). Le sacré et son inscription dans l'espace à Byzance et en Occident. Paris: Publications de la Sorbonne, 2001, pp. 13-24).

82 Los anales francos mencionan la reunión y la disputa entre romanos y griegos sobre la Trinidad et sanctorum imaginibus. Annales regni Francorum, s. a. 767 (Pertz y Kurze (eds.). MGH in usum scholarum, p. 24); Annales Mettenses priores, s. a. 767 (Simson, B. von (ed.). MGH in usum scholarum, p. 54).

83 Que es la única que conservamos, Codex Carolinus, n. 36 (Gundlach (ed.). MGH, Epp. III, Mer. et Kar. Aevi, I, Berlin, 1892).

${ }_{84}$ Codex Carolinus, n. ${ }^{\circ}$ 30, p. 536 y n. ${ }^{\circ}$ 36, p. 545. Los Graeci quieren destruere et conculcare esa fe y tradición (n. $\left.{ }^{\circ} 30\right)$ y se ha producido un debate de posturas ante el rey franco (in vestri praesentia disputantes altercati sunt (n. ${ }^{\circ}$ 36). No es irrelevante la acusación de ir contra la tradición. La utilizarán con otro sentido los Libri Carolini.

85 C. 4: Si ad sanctorum consortium venire optamus, profecto hic omnia in honore sanctorum, siue reliquias non solum corporum sed \& vestimentorum, siue basilicas nominibus eorum memoratas, seu etiam imagines \& vultus illorum in quolibet loco depictos celeberrimo honore venerari debemus. Pauendum est ne sub iconum occasione ad peiora sese status malae assertionis erigat, \& corpora sanctorum \& reliquias martyrum adorari tanquam membra domini ac venerari prohibeat. Lo edita Holstenius, Lucas. Collectio romana bipartita. Romae: Typis Iacobi Dragondelli, 1662, pp. 261s; y Mansi (ed.). Sacrorum conciliorum. XII, col. 720. 
se podrán consagrar iglesias si no se depositan reliquias en los altares ${ }^{86}$. Afirmación que parece combatir alguna propuesta de los iconoclastas, desarrollada probablemente tras el concilio de Hiereia del $754^{87}$. Es decir, hay elementos suficientes para pensar que entre sectores de la iconomaquia se desarrolló un distanciamiento del culto a las reliquias. No se trata de una actividad directamente hostil y menos de unas políticas volcadas a combatir o desterrar su culto, pero sí parece haber habido alguna sensibilidad minimizadora de su presencia.

El tema había saltado al ámbito franco. La relación entre el culto a las imágenes y el de las reliquias apareció en el Capitulare adversus synodus, la inmediata respuesta de la Iglesia franca a las medidas tomadas en el concilio de 787, en el que el Imperio oriental recuperaba el culto a las imágenes. Al documento respondió Adriano a requerimientos de Carlomagno. El papa parece haber estado preocupado porque se asimilaran ambas devociones, como parecen haber apuntado los carolingios ${ }^{88}$. Unos años más tarde volvió a aparecer el tema, dando lugar a una reunión eclesiástica en París en 825, aunque ahora desde unas posiciones más moderadas, quizá mostrando una leve reubicación carolingia $^{89}$.

Entre estos colectivos de la Bética hubo una cierta sensibilidad frente al culto a las reliquias que sus oponentes describieron como una negativa a promover su importancia o, incluso, su aceptación. El concilio cordobés los acusa de no instalar reliquias en sus iglesias, como parecen haber hecho estos orientales. No se trataba, ciertamente, de ninguna línea influenciada por el papado, pues en Roma se promocionaba su culto ${ }^{90}$. Con esta actitud quizá se ponía en duda la capacidad de los santos, pero, sobre todo, la de sus restos físicos para interceder ante Dios e intervenir en los asuntos humanos, lo que resultaba una afirmación paralela a la de Claudio de Turín y opuesta a lo que había sido

86 Canon 7. Se dispone que sería depuesto el obispo que consagrara iglesias absque limpsanis (LAMBERz (ed.), Acta Conciliorvm Oecvmenicorvm. III, p. 909; Joannou, Pericles-Pierre (ed.). Discipline générale antique, I. 1. Les canons des conciles oecuméniques. Roma: Tipografia Italo-Orientale, 1962, pp. 260s).

87 Gerö, Stephen. Byzantine Iconoclasm during the Reign of Constantine V, with Particular Attention to the Oriental Sources. Louvain: Secrétariat du Corpus SCO, 1977, p. 153. Gerö subraya que es más dudosa la contemporaneidad de otras fuentes y la fabulación del relato de Teófanes sobre las reliquias de Santa Eufemia. En el mismo sentido, Wortley, John T. «Iconoclasm and Leipsanoclasm: Leo III, Constantine V and the Relics». En Studies on the Cult of Relics in Byzantium up to 1204. Aldershot: Variorum, 2009, pp. 253-279 (sobre Eufemia, pp. 274ss).

${ }^{8}$ Ep. 2 (MGH, Epist. Karol. aevi, III, p. 14). Lo advierte Freeman, Ann. «Carolingian orthodoxy and the fate of the Libri Carolini». Viator, 1985, vol. 16, p. 74. Sobre los efectos del debate en el ámbito carolingio, Noble, Thomas F. X. Images, Iconoclasm, and the Carolingians. Philadelphia: Univiversity of Pennsylvania Press, 2009.

89 Los conciliares acudieron, como sus colegas cordobeses, al texto de Jerónimo contra Vigilancio para señalar la ortodoxia de la veneración a las reliquias (Concilio del 825, XLVII; MGH, Concilia II/2, p. 496).

90 Sobre el culto a las reliquias en Roma, Thacker, Alan. «Rome of the Martyrs: Saints, Cults and Relics, Fourth to Seventh Centuries». En Ó Carragáin, Éamonn y Neuman de Vegvar, Carol (eds.). Felix Roma: The Production, Experience and Reflection of Medieval Rome. Abingdon: Ashgate, 2008, pp. 13-50. McCulloh, John M. «From antiquity to the middle ages: continuity and change in papal relic policy from the $6^{\text {th }}$ to the $8^{\text {th }}$ century». En Dassmann, Ernst y Frank, K. Suso (eds.). Pietas: Festschrift für Bernhard Kötting. Münster: Aschendorff, 1980, pp. 313-324. 
tendencia general en Occidente ${ }^{91}$. Habida cuenta la referencia a que estos grupos o alguno de sus líderes parecen haber llegado por vía marítima, no resulta demasiado arriesgado suponer alguna influencia oriental que no podemos precisar. Con todo, lo destacable es que se estaban analizando y condenando unas propuestas que con esta cronología afloraban en diversos espacios europeos, revelando la generalización del asunto. En nuestro caso se combinaban con elementos de rigorismo y con tendencias adversas a concesiones con el medio social. Probablemente como retorno a posiciones primitivas colocaban silices en vez de reliquias en los altares, quizá incardinándose en la tradición judaica (Ex., 20, 25; Deut., 27, 5), pero claramente desterrando esa importante función de los restos de los santos. En cualquier caso, su rechazo ante estas manifestaciones de la religiosidad afectaría negativamente la influencia de algunos centros eclesiásticos, debilitando la situación de iglesias y monasterios poderosos en los que se conservaran cuerpos de mártires y confesores. Unos centros que protagonizaban la relación con esos santos y sus restos y que veían negado por los disidentes el papel intercesor de las reliquias y subsidiariamente el de las iglesias y monasterios que las acogían. Otras dinámicas de este colectivo perjudicaron a la jerarquía eclesiástica.

El primer canon del concilio marca habitualmente la línea general y revela buena parte de las posiciones de unos y otros. Allí se señala la prohibición de que se consagren obispos absoluti, lo que entendemos como sin sede determinada. Más aún se recalca que no pueden designarse obispos para sedes sin la solicitud de esas mismas ciudades y poblaciones. La tradición ya prohibía algunas designaciones episcopales ${ }^{22}$, o podía advertir contra quienes eran recibidos siendo extraños ${ }^{93}$, pero aquí se es más explícito. La fórmula es original dentro de la tradición hispana y subraya la prohibición de las ordenaciones no ligadas a una ciudad o iglesia, empleando absolutus en este sentido. El término sí se había usado en la tradición romana y franca. Así se había condenado a unos notorios obispos, llamados Aldeberto y Clemente, que a pesar de las sanciones seguían predicando, por lo que Bonifacio se sintió obligado a escribir al papa Zacarías. Este Aldeberto había sido ordenado por unos obispos indoctos, se sentía un verdadero apóstol, hasta el punto de

91 Sobre las reliquias y su culto, SANSTERrE, Jean-Marie. «Les justifications du culte des reliques dans le haut Moyen Âge». En Bozóky, Edina y Helvétıus, Anne-Marie (eds.). Les reliques. Objets, cultes, symboles. Actes du colloque international de l'Université du Littoral-Côte d'Opale (Boulogne-sur-Mer), 4-6 septembre 1997. Turnhout: Brepols, 1999, pp. 81-93. Además, Appleby, David F. "Holy Relic and Holy Image: Saints' Relics in the western controversy over images in the eighth and ninth Centuries». Word \& Image, 1992, vol. 8, n. ${ }^{\circ} 4$, pp. 333-343.

92 El concilio de Laodicea (c. 57. Martínez Díez y Rodríguez (eds.). Colección canónica hispana. III, p. 170) condenaba la ordenación de obispos in vicis o in villis; y el II de Cartago prohibía establecerlos donde antes no hubiera habido (c. 5, p. 304) o sin la aquiescencia del metropolitano (c. 12, p. 310). El XII concilio de Toledo del 681, frente a las decisiones de Wamba, recogió todos estos precedentes (c. 4; MARTínez Díez, Gonzalo y Rodríguez, Félix. La colección canónica hispana. VI. Concilios hispánicos. Madrid: Consejo Superior de Investigaciones Científicas, 2002, pp. 160ss). 434). 
que había erigido oratoria bajo su personal advocación ${ }^{94}$. No obstante, no parece haber tenido una sede concreta y nuestras fuentes lo muestran vagando por el territorio.

Si estamos en lo correcto, hay una gran posibilidad de que los conciliares del 839 estuvieran suficientemente familiarizados con disposiciones que procedían de un ambiente franco-romano. De hecho, en buena medida el debate giró en torno al papel de Roma. Migecio afirmaba que solo en Roma se encontraba el poder de Dios (potestas Dei) y la santidad, en tanto que allí habitaba Cristo ${ }^{95}$. Sin duda, era un modo de sobredimensionar la autoridad de Roma. Ella es la Jerusalén descendida de los cielos, por tanto la ciudad santa, dispuesta como esposa (Apoc. 21, 2). Solemos entender estas frases como parte del desvarío migeciano, sin advertir que no solo implican una toma de posición, también, cuanto menos, suponen una familiaridad con las manifestaciones y tradiciones romanas. Quienes discreparon de ellos debieron, igualmente, alcanzar cierto conocimiento de las mismas.

Hay una posible muestra de esa estrecha relación con los mensajes provenientes de Roma. En el Concilio parece haber una alusión al texto de la carta de Adriano. Los casianistas son definidos como aquellos que se mueven por vías tortuosas, per tortuosam callem gradientes, en lo que puede ser no solo una referencia genérica a Num., 21, 22, sino también a la epístola escrita por Adriano a sus enviados en al-Andalus ${ }^{96}$. El asunto es relevante, pues indicaría una voluntad manifiesta por parte de los conciliares de responder críticamente a las dinámicas romanas. La carta de Adriano habría sido divulgada muy probablemente a instancias de los disidentes que derivarían su legitimidad de los vínculos con el papado.

Ya no hay en el concilio mención alguna a posibles desviaciones trinitarias. Sin embargo, el propio nombre del grupo que se consolida servía como una potente señal que implicaba la heterodoxia teológica de la secta. Mas lo que ahora reforzaba esa condición era la continuidad de la desobediencia y de su marginalidad con respecto a las tradiciones y a la autoridad toledana. El grupo y sus líderes se comportaban como Datán y Abirón con respecto a Moisés. Al igual que los casianos, se proclamaban santos y promovieron la rebelión contra Moisés y Aarón. Frente a ellos el concilio parece proponer una actitud comparable a la bíblica, el aislamiento del grupo con respecto a la comunidad, pero también con la liquidación de su templo y su colectivo.

94 Concilium romanum (745). Werminghoff (ed.). MGH, Concilia, II, 1, pp. esp. 38ss. Además: contra praecepta canonum absolute ordinarunt (lo encontramos en el Capitulare Episcoporum de Carlomagno (780?): ut nullus absolute ordinetur (c. 25, p. 55); y en el Concilio de Frankfurt del 794, al mencionar la obligación de los clérigos de permanecer en un lugar (c. 28, p. 76); también presente en la Colección de Ansegis, 25. De presbyteris non absolute ordinandis. G. Schmitz (ed.): MGH, Capitularia, N. S. I, Hannover, p. 452). Algunas de las pautas de Aldeberto se parecen a las de Migecio, girando todo ello en su asimilación al propio Cristo.

95 Ep. I, 12 y 13.

96 Pro quo regia gradiemur via et non declinabimus penitus per tortuosam et dumis ac tribulis repletam callem... (Codex Carolinus, 95. Gundlach (ed.). MGH, Epp. III, Mer. et Kar. Aevi, I, Berlín, 1892, p. 641). 
El conflicto migeciano-casianista nos pone en contacto con las dificultades de la Iglesia hispana post-visigoda para mantener sus tradiciones y su jerarquización. A pesar de todo, es capaz de elaborar respuestas y de enfrentarse a quienes sintió como graves amenazas al mantenimiento de las coordenadas tradicionales. Las amenazas se manifestaban con claridad en su aislamiento y en su pretensión de santidad frente a las estructuras existentes. En estos debates, si se pone de manifiesto la vigencia de la cultura eclesiástica, también se deja sentir la necesidad de dar cuenta de las nuevas realidades sociales y culturales, asimismo de enfrentarse a otros posicionamientos y otras traditiones que no eran las hispanas y que la jerarquía entendió como desafíos al organigrama que tenía a Toledo como cabeza. En este enfrentamiento subrayó los componentes que le sirvieron para presentar a este colectivo como una herejía, asociando sus posturas a las de heterodoxias conocidas desde antiguo. En el caso de Elipando se acude, incluso, a la construcción de un personaje promotor del error (Migecio), del que se bosquejan -probablemente con algún, pero mediocre, fundamento- planteamientos teológicos disparatados. Además, se procede a describir, como no era anómalo, una personalidad alejada de la santidad que proclamaba. Mas, cuando entramos en los pormenores de esa divergencia, se advierten prácticas diferentes que afectan a cuestiones no doctrinales. La respuesta, mucho más comedida por parte del concilio cordobés, recorrerá estos elementos. Con ambas actuaciones - la de Elipando y la conciliar- la Iglesia hispana dirigida por Toledo no solo señalaba y condenaba a un colectivo, también se autoafirmaba como la sola garante de la ortodoxia y de la unidad cristiana. Los musulmanes aparecen en las fuentes que conservamos como colectivo con el que pueden mantenerse actitudes diversas. Los casianistas parecen haber mantenido un talante más renuente a los contactos, pero tampoco plenamente consistente. Lo relevante es que los definidos como herejes se comportan de manera diferente a la establecida y en ello y en otras conductas se alejan de las pautas hispanas. La jerarquía, cuya condición se apoyaba en las tradiciones del reino visigodo, defendía ese pasado y todos sus hallazgos y se enfrentaba a los disidentes internos y a las que consideraba sus referencias exteriores.

\section{REFERENCIAS BIBLIOGRÁFICAS}

AbAdAl, Ramon d'. La batalla del adopcionismo en la desintegración de la Iglesia visigoda. Barcelona: Real Academia de Buenas Letras, 1949.

Agustín de Hipona. De civitate Dei. Hofmann, E. (ed.). Viena: CSEL-40, 1899.

Alexander, James S. «The Motive for a Distinction between Donatus of Carthage and Donatus of Casae Nigrae». The Journal of Theological Studies, 1980, vol. 31, n. ${ }^{\circ} 2$, pp. 540-547.

Appleby, David F. «Holy Relic and Holy Image: Saints' Relics in the western controversy over images in the eighth and ninth Centuries». Word \& Image, 1992, vol. 8, n. ${ }^{\circ} 4$, pp. 333-343.

Auzépy, Marie-France. «Les Isauriens et l'espace sacré: L'église et les reliques». En Kaplan, Michel (ed.). Le sacré et son inscription dans l'espace à Byzance et en Occident. Paris: Publications de la Sorbonne, 2001, pp. 13-24. 
Barbero, Abilio. «El conflicto de los Tres Capítulos y las iglesias hispánicas en los siglos vi y viI». Studia Historica. Historia Medieval, 1987, vol. 5, pp. 123-144.

Barbero, Abilio. «El priscilianismo, ¿herejía o movimiento social?». En Conflictos y estructuras sociales en la Hispania antigua. Madrid: Akal, 1986, pp. 77-114.

Barnes, T. D. "The Beginnings of Donatism». The Journal of Theological Studies, 1975, vol. 26, n. ${ }^{\circ} 1$, pp. $13-22$.

Bitterauf, Theodor. Die Traditionen des Hochstifts Freising. I Band (744-926). München: M. Rieger'sche Universitäts-Buchhandlung: 1905.

Blaudeau, Philippe. "Narrating Papal Authority (440-530): The Adaptation of the Liber Pontificalis to the Apostolic See's developing Claims». En Dunn, Geoffrey D. (ed.). The Bishop of Rome in Late Antiquity. Farnham: Routledge, 2015, pp. 127-140.

Boureau, Alain. "Les théologiens carolingiens devant les images religieuses. La conjoncture de 825». En Boesprlug, François y Lossky, Nicolas (eds.). Nicée II, 787-1987. Paris: Éditions du Cerf, 1987, pp. 247-262.

Brown, Peter. "Aspects of the Christianization of the Roman Aristocracy». The Journal of Roman Studies, 1961, vol. 51, pp. 1-11.

Bullough, Donald. "The Dating of Codex Carolinus n. ${ }^{0 s}$ 95, 96, 97, Wilchar, and the Beginnings of the Archbishopric of Sens». Deutsches Archiv für Erforschung des Mittelalters, 1962, vol. 18, n. ${ }^{\circ}$ 1, pp. 223-230.

Cameron, Averil. "How to read Heresiology». Journal of Medieval and Early Modern Studies, 2003, vol. 33, n. ${ }^{\circ}$ 3, pp. 471-492.

Cappuyns, M. «Lorigine des "Capitula" d'Orange 529». Recherches de Théologie Ancienne et Médiévale, 1934, vol. 6, pp. 121-142.

Carola, Joseph. Augustine of Hippo: The Role of the Laity in Ecclesial Reconciliation. Roma: Editrice Pontificia Università Gregoriana, 2005.

Cavadini, John C. The Last Christology of the West. Adoptionism in Spain and Gaul, 785-820. Philadelphia: University of Pennsylvania Press, 1993.

Cazier, P. (ed.). Isidori Hispalensis Sententiae. CCSL-111. Turnholt: Brepols, 1998.

Chazelle, Celia y Cubitt, Catherine (eds.). The Crisis of the Oikoumene: The Three Chapters and the Failed Quest for Unity in the Sixth Century Mediterranean. Turnhout: Brepols, 2007.

Close, Florence. Uniformiser la foi pour unifier l'empire. Bruxelles: Académie Royale de Belgique, 2011.

Collins, Roger. Caliphs and Kings: Spain, 796-1031. Oxford: Wiley-Blackwell, 2012.

Cordiolani, Alfred. «Textos de cómputo español del siglo vi. El 'prologus Cyrilli'». Hispania Sacra, 1956, vol. 9, pp. 127-139.

Dagron, Gilbert. «L'ombre d'un doute: L'hagiographie en question, $\mathrm{VI}^{\mathrm{e}}-\mathrm{XI}^{\mathrm{e}}$ siècle». Dumbarton Oaks Papers, 1992, vol. 46, pp. 59-68.

Dekkers, E. (ed.). Tertulliani Opera. Turnholt: Brepols CCSL-1, 1954.

Doвschüтz, Ernst von (ed.). Das Decretum Gelasianum de libris recipiendis et non recipiendis. Leipzig: Hinrichs, 1912.

Duchesne, Louis. "Wilchaire de Sens, archevêque des Gaules». Bulletin de la Société Archéologique de Sens, 1895, vol. 17, pp. 15-22.

Dümmler, Ernest (ed.). Monumenta Germaniae Historica. Epistolae Karolini aevi. Tomus II. Berolini: Apud Widmannos, 1895).

Elm, Susanna. "The polemical use of genealogies: Jerome's classification of Pelagius and Evagrius Ponticus». En Livingstone, Elizabeth (ed.). Augustine and his Opponents. Studia Patristica, 1997, vol. XXXIII, pp. 311-318. 
FÉrotin, Marius. Le Liber Ordinum en usage dans l'Église wisigothique et mozarabe d'Espagne du cinquième au onzième siècle. Roma: Edizioni Liturgiche, 1996.

Freeman, Ann. «Carolingian orthodoxy and the fate of the Libri Carolini». Viator, 1985, vol. 16, pp. 65-108.

Gams, Pius Bonifacius. Die Kirchengeschichte von Spanien. Regensburg: Verlag von Georg Joseph Manz, 1864, vol. II.

Gardner, Iain y Lieu, Samuel N. C. (eds.). Manichaean Texts from the Roman Empire. Cambridge: Cambridge University Press, 2004.

Gaudemet, Jean y Basdevant, Brigitte. Les canons des conciles mérovingiens (VI -VII siècles). Sources Chrétiennes, 353. Paris: Éditions du Cerf, 1989.

Gerö, Stephen. "Notes on Byzantine iconoclasm in the eighth century». Byzantion, 1974, vol. 44, n. ${ }^{\circ} 1$, pp. $23-42$.

Gerö, Stephen. Byzantine Iconoclasm during the Reign of Constantine V, with Particular Attention to the Oriental Sources. Louvain: Secrétariat du Corpus SCO, 1977.

GIL, Juan. Corpus scriptorum muzarabicorum. Madrid: Consejo Superior de Investigaciones Científicas, 1973.

Gómez Pallarés, Joan. «El cómputo eclesiástico en la España de la escritura visigótica a través de sus manuscritos y textos». Miscellània en homenatge al P. Agustí Altisent. Tarragona: Diputació de Tarragona, 1991, pp. 461-468.

Hefele, Charles-Joseph. Histoire des conciles d'après les documents originaux. Paris: Letouzey et Ané, 1908, vol. II, pt. 1; 1910, vol. III, pt. 2.

Helm, Rudolf (ed.). Die Chronik des Hieronymus. Leipzig, 1913.

Holstenius, Lucas. Collectio romana bipartita. Romae: Typis Iacobi Dragondelli, 1662.

Hunter, David. Marriage, Celibacy, and Heresy in Ancient Christianity: The Jovinianist Controversy. Oxford: Oxford University Press, 2009.

Hwang, Alexander Y. Intrepid lover of Perfect Grace: The Life and Thought of Prosper of Aquitaine. Washington, DC: The Catholic University of America Press, 2009.

Isıdoro. Chronica. Martín, José Carlos (ed.). Turnhout: Brepols, CCSL-112, 2003.

Isıdoro. Etymologiae. Lindsay, W. M. (ed.) Oxford: Oxford University Press, 1911.

Isla Frez, Amancio. "El adopcionismo y las evoluciones religiosas y políticas del reino astur». Hispania, 1998, vol. 58, n. ${ }^{\circ}$ 200, pp. 971-993.

Isla Frez, Amancio. «El adopcionismo. Disidencia religiosa en la Península Ibérica (fines del siglo viII-principios del siglo IX)». Clio \& Crimen, 2004, vol. I, pp. 114-134.

Jefford, Clayton N. (trad.). Didache. The teaching of the twelve apostles. Salem, OR: Polebridge Press, 2013.

Joannou, Pericles-Pierre (ed.). Discipline générale antique, I. 1. Les canons des conciles oecuméniques. Roma: Tipografia Italo-Orientale, 1962.

JonG, Mayke de. «An unsolved riddle: early medieval incest legislation». En Wood, Ian (ed.). Franks and Alamanni in the Merovingian period: an ethnographic perspective. Woodbridge: Boydell Press, 1998, pp. 107-140.

Judic, Bruno (ed.). La Règle pastorale. Sources Chrétiennes, 381. Paris: Éditions du Cerf, 1992.

Lamberz, Erich (ed.). Acta Conciliorvm Oecvmenicorvm. III. Concilium universale Nicaenum II. Concilii actiones I-III. Berlin-New York: De Gruyter, 2008.

Laмвот, Cyrille (ed.). Oeuvres théologiques et grammaticales de Godescalc d'Orbais. Louvain: Spicilegium Sacrum Lovaniense, 1945.

Louth, Andrew. St. John Damascene: Tradition and Originality in Byzantine Theology. Oxford: Oxford University Press, 2002. 
MacDonald, Margaret. «Early Christian women married to unbelievers». Studies in Religion/ Sciences Religieuses, 1990, vol. 19, n. ${ }^{\circ}$ 2, pp. 221-234.

MacDonald, Margaret. "Was Celsus Right? The Role of Women in the Expansion of Early Christianity». En Balch, David L. y Osıek, Carolyn (eds.). Early Christian Families in Context. An Interdisciplinary Dialogue. Grand Rapids: Eerdmans, 2003, pp. 157-184.

Madoz, José. Epistolario de Álvaro de Córdoba. Madrid: Consejo Superior de Investigaciones Científicas, 1947.

Markus, Robert A. Saeculum. History and society in the theology of St Augustine. Cambridge: Cambridge University Press, 2007.

Martín Iglesias, José Carlos. «La biblioteca cristiana de los padres hispanovisigodos (siglos VIvII)». Veleia, 2013, vol. 30, pp. 259-288.

Martínez Díez, Gonzalo y Rodríguez, Félix. La colección canónica hispana. III. Concilios griegos $y$ africanos. Madrid: Consejo Superior de Investigaciones Científicas, 1982.

Martínez Díez, Gonzalo y Rodríguez, Félix. La colección canónica hispana. IV. Concilios galos. Concilios hispanos. Madrid: Consejo Superior de Investigaciones Científicas, 1984.

Martínez Díez, Gonzalo y Rodríguez, Félix (eds.). La colección canónica hispana. V. Concilios hispanos. Madrid: Consejo Superior de Investigaciones Científicas, 1992.

Martínez Díez, Gonzalo y Rodríguez, Félix. La colección canónica hispana. VI. Concilios hispánicos. Madrid: Consejo Superior de Investigaciones Científicas, 2002.

Marx, F. (ed.). Diversarum hereseom liber. Viena: CSEL-38, 1898.

Mathisen, Ralph W. «Barbarian Bishops and the Churches "in Barbaricis Gentibus" during Late Antiquity». Speculum, 1997, vol. 72, n. ${ }^{\circ}$ 3, pp. 664-697.

McCulloH, John M. «From antiquity to the middle ages: continuity and change in papal relic policy from the $6^{\text {th }}$ to the $8^{\text {th }}$ century». En Dassmann, Ernst y Frank, K. Suso (eds.). Pietas: Festschrift für Bernhard Kötting. Münster: Aschendorff, 1980, pp. 313-324.

Menéndez y Pelayo, Marcelino. Historia de los heterodoxos españoles. Madrid: Librería Católica de San José, 1880-1881, 3 vols.

Nathan, Geoffrey S. The Family in Late Antiquity: The rise of Christianity and the endurance of tradition. London-New York: Routledge, 2000.

NeLson, Janet L. King and Emperor. A New Life of Charlemagne. Oakland: University of California Press, 2019.

Noble, Thomas F. X. Images, Iconoclasm, and the Carolingians. Philadelphia: University of Pennsylvania Press, 2009.

Ogliari, Donato. Gratia et Certamen: The Relationship between Grace and Free Will in the Discussion of Augustine with the so-called Semi-Pelagians. Leuven: Leuven University Press, 2003.

Oliver, Antonio. «Félix de Urgel y el adopcionismo». En García Villoslada, Ricardo (ed.). Historia de la Iglesia en España. Madrid: Biblioteca de Autores Cristianos, 1979, vol. II, tomo 1, p. 89.

Pelikan, Jaroslav. The Christian tradition: A history of the development of doctrine, vol. 1: The emergence of the Catholic tradition (100-600). Chicago: University of Chicago Press, 1975.

Petschenig, Michael (ed.). Iohannis Cassiani Opera. I, Viena: Apud C. Geroldi Filium, 1888, CSEL-17.

RAAIJMAKers, Janneke E. y van Renswoude, Irene. "The ruler as referee in theological debates: Reccared and Charlemagne». En Meens, Rob et al. (eds.). Religious Franks. Religion and Power in the Frankish Kingdoms. Studies in Honour of Mayke de Jong. Manchester: University Press, 2016, pp. 51-71. 
Raepsaet-Charlier, Marie-Thérèse. «Tertullien et la législation des mariages inégaux». Revue Internationale des Droits de l'Antiquité, 1982, vol. 29, pp. 253-263.

Rivera Recio, Juan Francisco. El adopcionismo en España (s. VIII). Toledo: Seminario Conciliar de San Ildefonso, 1980.

Rivera Recio, Juan Francisco. Elipando de Toledo. Toledo: Editorial Católica Toledana, 1940.

Salzman, Michele Renee. The Making of a Christian Aristocracy. Social and Religious Change in the Western Roman Empire. Cambridge: Harvard University Press, 2002.

Sansterre, Jean-Marie. "Les justifications du culte des reliques dans le haut Moyen Âge». En Bozóky, Edina y Helvétius, Anne-Marie (eds.). Les reliques. Objets, cultes, symboles. Actes du colloque international de l'Université du Littoral-Côte d'Opale (Boulogne-sur-Mer), 4-6 septembre 1997. Turnhout: Brepols, 1999, pp. 81-93.

Shaw, Brent. «African Christianity: Disputes, Definitions, and 'Donatists'». En Greenshields, Malcolm R. y Robinson, Thomas Arthur (eds.). Orthodoxy and Heresy in Religious Movements: Discipline and Dissent. Lewiston, N.Y.: Edwin Mellen Press, 1992, pp. 5-34.

Simonet, Francisco Javier. Historia de los mozárabes de España. Madrid: Est. Tip. de la Viuda e Hijos de M. Tello, 1897-1903.

Stewart, Columba. Cassian the Monk. Oxford: Oxford University Press, 1998.

Sulpicio Severo. Vita Martini. Halm, K, (ed.). Viena: CSEL-20, 1866.

Thacker, Alan. «Rome of the Martyrs: Saints, Cults and Relics, Fourth to Seventh Centuries». En Ó Carragáin, Éamonn y Neuman de Vegvar, Carol (eds.). Felix Roma: The Production, Experience and Reflection of Medieval Rome. Abingdon: Ashgate, 2008, pp. 13-50.

Thomson, H. J. (ed.). Prudentius. Cambridge, Mass.: Harvard University Press, 1953, vol. II.

Tieszen, Charles. Christian identity amid Islam in medieval Spain. Leiden: Brill, 2013.

Turner, C. H. "The Liber ecclesiasticorum dogmatum attributed to Gennadius». The Journal of Theological Studies, 1905, vol. VII, n. ${ }^{\circ} 25$, pp. 78-99.

Ullmann, Walter. "Leo I and the theme of papal primacy». The Journal of Theological Studies, 1960, vol. 11, n. ${ }^{\circ}$, pp. 25-51.

Unvoy, Dominique. «La pensée religieuse des mozarabes face à l'islam». Traditio, 1983, vol. 39, pp. 419-432.

Urvoy, Dominique. "The Christological Consequences of Muslim-Christian Confrontation in Eighth-Century Spain». En Fierro, M. ${ }^{a}$ Isabel y SAmsó, Julio (eds.). The Formation of alAndalus, 2: Language, religion, culture and sciences. Aldershot: Taylor \& Francis, 1998, pp. 37-50.

Vega, Ángel C. (ed.). España Sagrada, t. LIII-LIV. Madrid: Maestre, 1961.

VIves, José (ed). Concilios visigóticos e hispano-romanos. Barcelona-Madrid: Consejo Superior de Investigaciones Científicas, 1963.

Wessel, Susan. Leo the Great and the Spiritual Rebuilding of a Universal Rome. Leiden-Boston: Brill, 2008.

Williams, Frank (ed.). The Panarion of Epiphanius of Salamis Book I. Leiden: Brill, 2009.

Wilson, Henry A. The Gelasian Sacramentary: Liber sacramentorum Romanae Ecclesiae. Oxford: Clarendon, 1894.

Wortley, John T. «Iconoclasm and Leipsanoclasm: Leo III, Constantine V and the Relics». En Studies on the Cult of Relics in Byzantium up to 1204. Aldershot: Variorum, 2009, pp. 253279.

Wortley, John T. «Icons and Relics». Greek, Roman, and Byzantine Studies, 2002-2003, vol. 43, pp. 161-174. 